Illinois State University

ISU ReD: Research and eData

Theses and Dissertations

2-15-2017

\title{
Rights of Nature and the Political Implications of Post-Humanist Ecologies
}

Jaimie Kent

Illinois State University, jaimie.kent@gmail.com

Follow this and additional works at: https://ir.library.illinoisstate.edu/etd

Part of the Political Science Commons

\section{Recommended Citation}

Kent, Jaimie, "Rights of Nature and the Political Implications of Post-Humanist Ecologies" (2017). Theses and Dissertations. 686.

https://ir.library.illinoisstate.edu/etd/686

This Thesis is brought to you for free and open access by ISU ReD: Research and eData. It has been accepted for inclusion in Theses and Dissertations by an authorized administrator of ISU ReD: Research and eData. For more information, please contact ISUReD@ilstu.edu. 


\title{
RIGHTS OF NATURE AND THE POLITICAL IMPLICATIONS OF POST-HUMANIST \\ ECOLOGIES
}

\author{
Jaimie Kent
}

\section{Pages}

Several countries have adopted legal frameworks that recognize 'nature,' or nonhuman things in 'nature,' as rights-bearing entities in their own right. In this thesis, I ask what these laws can tell us about the possible political implications of post-humanist perspectives regarding nonhuman entities and 'nature.' To answer this question, I analyze the similarities and differences between recent post-humanist ecological perspectives (Bennett 2010; Latour 2014, 2004) and indigenous imaginaries that informed rights of nature laws in Ecuador, Bolivia, and New Zealand. This comparative analysis reveals a promising path for achieving sustainable relationships with nonhuman entities that promote environmental protection. Finally, I discuss some of the challenges involved in adopting post-humanist perspectives in the political and legal sphere. I conclude that while it is not without obstacles, the inclusion of post-humanist theories of ecology in legal frameworks can potentially encourage and reinforce ecologically-minded cultural attitudes.

KEYWORDS: Rights of Nature; Post-Humanist Ecology; Indigenous Cosmologies; Vital Materialism 


\section{RIGHTS OF NATURE AND THE POLITICAL IMPLICATIONS OF POST-HUMANIST \\ ECOLOGIES}

JAIMIE KENT

A Thesis Submitted in Partial

Fulfillment of the Requirements

for the Degree of

MASTER OF SCIENCE

Department of Politics and Government

ILLINOIS STATE UNIVERSITY 
Copyright 2017 Jaimie Kent 


\section{RIGHTS OF NATURE AND THE POLITICAL IMPLICATIONS OF POST-HUMANIST \\ ECOLOGIES}

JAIMIE KENT

COMMITTEE MEMBERS:

Kam Shapiro, Chair

Michaelene Cox

Noha Shawki 


\section{ACKNOWLEDGMENTS}

I would first like to thank my thesis chair, Dr. Shapiro, who has been an immense inspiration to me. I could not have asked for a better advisor throughout this process and I am forever grateful to him for exposing me to the brilliant and intriguing world of political theory. He introduced me to post-humanist ecology and several other thought-provoking perspectives, allowing me understand the world through a very interesting set of lenses.

Thank you to Dr. Cox, who supported me and believed in me from day one. She first sparked my interest in rights of nature laws and let me endlessly ramble on during frequent visits to her office. Thank you to Dr. Shawki, who was my very first mentor at ISU. Her words of encouragement have gotten me through numerous hurdles and I am very grateful to her for this. I am also greatly indebted to the faculty and staff in the Department of Politics and Government at ISU. Every professor I have had has played an integral role shaping me into the truth-seeking activist and critic I am today.

Finally, a quick thanks to my sister Rachel and dear friend Kirsten for supporting me throughout this project. They both patiently listened to me rant for hours on end about climate change, nonhumans, 'nature,' politics, and everything in between.

Cheers to great professors, great friends, and great family - these lines are often blurred, and this research has certainly taught me that lines of separation exist only where we choose to define and perceive them. 


\section{CONTENTS}

Page

ACKNOWLEDGMENTS

$\begin{array}{ll}\text { CONTENTS } & \text { ii }\end{array}$

CHAPTER I: INTRODUCTION 1

CHAPTER II: POST-HUMANIST ECOLOGIES 6

Bennett's Vital Materialism: Assemblages and Edible Matter $\quad 6$

Latour's Parliament of Things: The Bifurcation of Nature, Matters of Concern, and

$\begin{array}{ll}\text { Spokespersons } & 11\end{array}$

Potential Political Implications of Post-Humanist Ecology 19

CHAPTER III: INDIGENOUS BELIEFS, PRACTICES, AND POST-HUMANIST

ECOLOGIES 22

$\begin{array}{ll}\text { Indigenous Amazonian Beliefs and Practices } & 23\end{array}$

Corporality and Assemblages 23

Plants, Shamanism, and Edible Matter $\quad 30$

Species Classification and Matters of Concern 35

Maori Beliefs and Practices $\quad 40$

$\begin{array}{ll}\text { Ecosystems and Assemblages } & 40\end{array}$

Ecosystem Health and Matters of Concern $\quad 44$

CHAPTER IV: RIGHTS OF NATURE LAW IN ECUADOR, BOLIVIA, AND NEW

$\begin{array}{ll}\text { ZEALAND } & 48\end{array}$

Rights of Nature in Ecuador $\quad 48$

Constitution of Ecuador $\quad 49$ 
Implementation and Enforcement $\quad 51$

Rights of Nature in Bolivia $\quad 54$

Bolivian Law on the Rights of Mother Earth 56

$\begin{array}{ll}\text { Implementation and Enforcement } & 58\end{array}$

Rights of Nature in New Zealand $\quad 60$

Whanganui River Deed of Settlement $\quad 62$

Implementation and Enforcement $\quad 63$

$\begin{array}{ll}\text { CHAPTER V: CONCLUSION } & 67\end{array}$

$\begin{array}{ll}\text { REFERENCES } & 70\end{array}$

APPENDIX A: ECUADORIAN CONSTITUTION (EXCERPT) 77

APPENDIX B: BOLIVIAN LAW ON THE RIGHTS OF MOTHER EARTH 78

APPENDIX C: NEW ZEALAND'S WHANGANUI RIVER DEED OF SETTLEMENT

$\begin{array}{ll}(\text { EXCERPT) } & 81\end{array}$ 


\section{CHAPTER I: INTRODUCTION}

There is broad scientific consensus that human interference in the natural world has created the current climate crisis, coupled with what some scientists refer to as the sixth major global extinction, defined by the loss of biodiversity. Humans have long interfered with the natural world, but the designation of our current geological epoch as the "Anthropocene" calls for a new consideration of the ways in which humans, politics, and ecology interact. Several states have recently begun to respond to these ecological crises by granting legal personhood to nonhuman entities through rights of nature legislation. Meanwhile, political theorists have argued for incorporating post-humanist theories of nonhuman agents and processes into the practice of politics (Bennett 2012; Latour 2014, 2004). My thesis explores intersections between post-humanist ecological theories and rights of nature laws in Ecuador, Bolivia, and New Zealand. Specifically, I ask what these rights of nature laws can tell us about the possible political implications of post-humanist ecologies. While I find that rights of nature laws reflect intersections between post-humanist ecological theories and indigenous conceptions of 'nature,' there are several concurrent practices that must follow if alternative perspectives regarding nonhuman entities are to be embedded in mainstream legal and political discourse. I argue that rights of nature laws reveal an evolving political context where post-humanist ecological theories merge with western-centered legal frameworks, potentially provoking and reinforcing a new ecological-mindedness.

There has been a lively debate in rights of nature discourse since Christopher Stone's 1972 essay, “Should Trees Have a Legal Standing?” However, the passage and implementation of rights of nature laws at the state level are a new phenomenon, stemming from indigenous peoples' movements in Ecuador, Bolivia, and New Zealand. In 2008, Ecuador worked the rights 
of nature into its constitution, granting legal status to all natural entities in 'nature' (Akchurin 2015; Erin Daly 2012). The Ecuadorian constitution recognizes nature's "right to exist, persist, maintain and regenerate its vital cycles" (Chapter XII, Article 71). Following Ecuador's lead, Bolivia hosted the World People's Conference on Climate Change in 2010, culminating in the Universal Declaration on the Rights of Mother Earth (UDRME). The UDRME declares that we "are all part of Mother Earth, an indivisible, living community of interrelated and interdependent beings with a common destiny" (GARN 2012). Following the World People's Conference, Bolivia passed the Law of the Rights of Mother Earth, embracing the main tenets of the UDRME (Sheehan 2015; Espinosa 2014). While Ecuador and Bolivia have focused on the broad legal rights of nature, New Zealand recently passed a law that provides legal status to the Whanganui River (Hsiao 2012; Magallanes 2015). Reached in 2014, the Whanganui River Deed of Settlement not only recognizes the river as a "living entity in its own right, incapable of being 'owned' in an absolute sense," but also as an "indivisible and living whole, from the mountains to the sea, incorporating its tributaries and all its physical and metaphysical elements" (Section 1). Each law attributes legal status to nonhuman entities while recognizing the interconnectedness of human and nonhuman bodies, exemplifying how indigenous Amazonians and the Maori of New Zealand understand human and nonhuman associations.

Although my thesis focuses exclusively on the legal status of nonhuman entities in rights of nature law, granting legal status to nonhuman entities is not entirely new. Corporations have had legal personhood status in the United States since the San Mateo County vs. Southern Pacific Rail Road case of 1886. During the case, U.S. Senator Roscoe Conkling argued that the 14th amendment, which stipulates that "no state shall ... deprive any person of life, liberty, or property without due process of law," should not be limited to natural persons (Torres-Spelliscy 2014). 
Advocates for the rights of animals have also pushed for laws that identify animals as rights bearing entities. In the past ten years, France, Germany, New Zealand and Canada have all recognized animals as sentient beings, worthy of special legal status (World Animal Protection 2014). Further, indigenous peoples have long held animist beliefs that do not distinguish personhood between humans and nonhumans. For animists, all nonhuman things possess some form of sentience and spiritual essence (Harvey 2006).

Indigenous groups of Amazonia and the Maori of New Zealand follow several tenets of animism in their regard for nonhuman entities. Indigenous beliefs about nonhumans and related cultural practices in Ecuador, Bolivia, and New Zealand played important roles in initiating and framing rights of nature laws. For indigenous Amazonians, human and nonhuman identities are intertwined in a constantly evolving state of metamorphosis and nonhumans play a significant role in communal healing practices. These beliefs translate into rights of nature laws in Ecuador and Bolivia, which recognize the deep kinship between indigenous peoples and 'nature.' Maori beliefs involving ancestral ties to nonhuman entities, and guardianship responsibilities to promote a balanced ecosystem also translate directly into New Zealand's Whanganui River Deed of Settlement. Although the legal frameworks in Ecuador, Bolivia, and New Zealand focus on different aspects of indigenous cosmologies, and have different implementation and enforcement mechanisms, they all recognize the importance of nonhuman entities in indigenous ways of life, highlighting a new public infusion of liberal and indigenous conceptions of human and nonhuman associations.

A reimagining of human and nonhuman associations has also been under way in socalled post-humanist theories of political ecology. In chapter II, I explore two prominent exemplars of these philosophies, namely Jane Bennett's (2012) 'vital materialism' and Bruno 
Latour's $(2004 ; 2014)$ 'parliament of things.' In particular, I interpret Bennett's notions of assemblage and edible matter as well as Latour's concepts of the bifurcation of nature, matters of concern, and spokespersons. My theoretical interpretation of Bennett and Latour's concepts provides the groundwork for comparing post-humanist ecologies with indigenous Amazonian and Maori beliefs and practices (chapter III) and rights of nature laws in Ecuador, Bolivia, and New Zealand (chapter IV). Post-humanist ecologies and indigenous imaginaries reveal alternative ways of reimagining human and nonhuman relationships that are contrary to western, anthropocentric views of 'nature' and nonhuman entities. The liberal individualism embedded in western philosophical traditions designates humans as individual agents whose interests and decisions are independent not only from each other, but also from nonhuman entities and 'nature.' Conceiving entities as independent and self-interested reinforces the exploitation of non-human beings, or 'nature' as a resource for human ends. In this scenario, agency belongs specifically to humans and it is only in their instrumental use value that nonhuman things are perceived as entities in need of protection. Indigenous practices, beliefs, and post-humanist ecological theories challenge these conceptions as they redefine human and nonhuman associations, creating a cultural disposition that does not conceive of humans as a dominating force over 'nature,' and an instrumental resource for exploitation. I highlight how these alternative notions are brought into modern political discourse through rights of nature laws, revealing several of the conceptual challenges and potential practical applications of posthumanist ecologies and ultimately answering my research question: What do rights of nature laws tell us about the political implications of post-humanist ecologies? (chapter V).

While post-humanist ecologies challenge western conceptions about 'nature,' and the interactions of human beings with nonhumans, they have been criticized for presenting 
themselves as radically new concepts in environmental discourse (Sundberg 2014; Blaser 2014; Hunt 2014; Diprose and Bond 2016). As Diprose and Bond (2016) point out, "complex understandings of more than human agency as a politicising force exist and are evident in daily life within many indigenous communities" (165). Indeed, there are many commonalities between post-humanist ecologies and indigenous beliefs and practices. By analyzing rights of nature laws in light of post-humanist ecologies, I hope to show that post-humanist ecologies can be effective because of their affinities with indigenous cosmologies, not in spite of them. Moreover, analyzing post-humanist ecologies through concrete legal frameworks provides a guidepost for determining the potential transferability of post-humanist theories into modern ecological movements. Nonhuman rights and the rights of nature are relatively new developments, and have not yet been embedded in mainstream academic discourse. Furthermore, the political implications of Bennett and Latour's post-humanist ecologies have not been adequately explored. This research helps to fill these gaps while also providing new avenues for investigating human-nonhuman assemblages as they are continually redefined in theory and practice. Finally, this research has broader value in terms of uncovering the ways in which humans, politics, and ecology interact. As we move into the unknown terrain of the Anthropocene, it is important to engage in new ways of understanding the interplay between humans and nonhumans and what these ecological imaginaries mean for our politics. 


\section{CHAPTER II: POST-HUMANIST ECOLOGIES}

As mentioned above, post-humanist ecologies conceive of human and nonhuman associations differently than western traditions that privilege human agency and subjectivity. Bennett and Latour both de-center the human as the only actor, arguing that nonhuman entities also possess affective capacities and agency. As they emphasize, nonhuman things can not only shape and influence human dispositions, but they can also disrupt and reconfigure the trajectories of human intentions. Indeed, interactions between humans and nonhumans are not static, onedirectional causalities, but dynamic processes. This section will serve as a guidepost for the rest of the paper-a reference point to which I frequently return throughout the chapters that follow. Here, I will unpack Jane Bennett's (2010) concept of assemblage, focusing on her discussion of edible matter and Bruno Latour's $(2004 ; 2014)$ discussion of the bifurcation of nature dilemma, matters of concern, and spokespersons. I then discuss what Bennett and Latour see as the potential virtues of post-humanist theories of ecology before comparing their concepts to indigenous beliefs and practices in the next chapter.

\section{Bennett's Vital Materialism: Assemblages and Edible Matter}

Jane Bennett's (2010) concepts of assemblage and edible matter are part of her larger project in which she asks: "How would political responses to public problems change were we to take seriously the vitality of (nonhuman) bodies?" (vii). The word vitality refers to the "capacity of things — edibles, commodities, storms metals — not only to impede or block the will and designs of humans but also to act as quasi agents or forces with trajectories, propensities, or tendencies of their own" (viii). I describe below how nonhuman things engage as vital materialities in an assemblage and how vital materiality works in Bennett's example of edible matter. Bennett's assemblages involve interactions between various human and nonhuman 
entities, where nonhuman things possess agency as 'actants.' Bennett borrows the term 'actant' from Bruno Latour for whom it is "something that acts or is something to which its activity is granted by others" (75). Further, Bennett quotes Gilles Deleuze, for whom "the power of a body to affect other bodies includes a 'corresponding and inseparable' capacity to be affected", as "there are two equally actual powers, that of acting, and that of suffering action" $(2010,22)$. While nonhuman actants can affect and be affected in turn, their affective capacities and agency can be transformed and even enhanced when they are part of an assemblage constituted by various other actants. A vital materialist's conception of agency is quite different from traditional forms of agency for several reasons. From a vital materialist perspective, agency is distributed across both human and nonhuman actants that are engaged in an assemblage. Bennett's description of an electrical power grid illustrates this point:

To the vital materialist, the electrical grid is better understood as a volatile mix of coal, sweat, electromagnetic fields, computer programs, electron streams, profit motives, heat, lifestyles, nuclear fuel, plastic, fantasies of mastery, static, legislation, water, economic theory, wire, and wood - to name just some of the actants (25).

As Bennett argues, the distribution of actants in an electric grid assemblage is especially noticeable in times of crisis, which was the case on the day of the Great North American Blackout of 2003:

What seems to have happened on that August day was that several initially unrelated generator withdrawals in Ohio and Michigan caused the electron flow pattern to change over the transmission lines, which led, after a series of events including one brush fire that burnt a transmission line and then several wire-tree-encounters, to a successive 
overloading of other lines... [causing] one generating plant after another to separate from the grid (25).

The Great North American Blackout was not caused by one actor or actant alone, but rather by a cascade of actants. This example demonstrates how the affective capacities of nonhumans can generate dynamic effects in an assemblage.

Because "power is not distributed evenly across the surface of an assemblage," vital materialism suggests that nonhuman actants can sometimes possess greater agency than human actors (24). An uneven distribution of agency has implications for human intentions as well as hierarchal, subject-object formulations of power relationships. The perception of nonhuman things as mute, static objects, consequently imbues humans with unique capacities of efficacy and action, ultimately solidifying the assumption that humans have power over other entities. Bennett's account of assemblage breaks down this construction. On the one hand, it suggests that human intention is always at risk of being blunted, or even transformed by other actants in the assemblages of which they are part. On the other hand, it assumes that power arrangements between people and nonhuman actants are often not hierarchal, and that humans are not always at the top. In this way, "intention is like a pebble thrown into a pond, or an electric current sent through a wire or neural network: it vibrates and merges with other currents, to affect and be affected" (32).

Rather than viewing humans as solitary agents, who act upon the passive world around them, vital materialism proposes that humans and nonhumans are in a constant flux of dynamic relationships. However, Bennett makes clear that the "political goal of vital materialism is not the perfect equality of actants, but a polity with more channels of communication between members" (141). Below, I explore how Latour's 'parliament of things' provides a means for 
bringing nonhuman entities into our politics, and opening up these "channels of communication between members." It is through an awareness of the vitality of nonhuman entities that a shift in perspective occurs for Bennett. Although "humanity and nonhumanity have always performed an intricate dance with each other" and there "was never a time when human agency was anything other than an interfolding network of humanity and nonhumanity," it is our recognition of the inexorable linkages between humans and nonhumans that we can build an ecologically-minded politics (31). Bennett's description of edible matter exemplifies potential lines of communication and "interfolding networks of humanity and nonhumanity" that affect our outward actions and dispositions.

More than blocking intentions, distributed actants can form and transform them. As Bennett points out, food is an "actant inside and alongside intention-forming, morality(dis)obeying, language-using, reflexivity-wielding, and culture-making human beings," and is an "inducer-producer of salient, public effects" (39). Edible matter acts quite literally within and through the human body, engaging in biological and chemical interactions that affect human thinking and volition. Bennett's description of the efficacy of fat helps to elucidate this point. She writes, "food coacts with the hand that places it in one's mouth" as the "metabolic agencies of intestines, pancreas, kidneys... and cultural practices of physical exercise," ultimately generate "new human tissue" (40). More surprisingly, so-called good fats, such as omega-3 fatty acids "can make prisoners less prone to violent acts, schoolchildren better able to focus, and bipolar persons less depressed" (41). In this way, fats can not only change one's physical appearance, but also their dispositions and sensibilities. As Bennett puts it, lipids can "promote particular human moods or affective states" (41). 
Taking nonhuman things like fat and other edible matter under consideration and acknowledging their capacity to shape human dispositions helps to reveal the significant effects of nonhuman actants in an assemblage. The ability of nonhuman things, such as fatty acids, to alter human states of mind, has real implications for the ways in which we interact socially and politically. If we are to thoroughly investigate social and political problems, it is not enough that we look at "economic-cultural prostheses" (43). We must instead explore the "strivings and trajectories of fats as they weaken or enhance the power of human wills, habits, and ideas" (43). For example, understanding how propensity for violence changes according to the intake of omega-3 fatty acids can implicate theories of criminal responsibility and change prison diets.

Another implication of this perspective is that agency does not require political and social objectives to produce social and political effects. Bennett uses the example of population disbursement to illustrate this point. Although people tend to "distribute themselves into racially and economically segregated neighborhoods," they are usually following cultural trends, and do not "intend, endorse, or even consider" their impact on political effects such as "municipal finances, crime rates, and transportation policy" (98). This interpretation of agency is useful in understanding how nonhuman entities can produce political effects through "cultural trends." That is, if we become conscious of the ways in which we interact with nonhuman entities, we can create a cultural disposition that fosters guardianship of nonhuman things in 'nature.' Moreover, if we understand that nonhuman entities share agency with humans, it becomes the self interest of humans to consider how we affect and are affected by nonhuman forces. While Bennett's concepts of assemblage and edible matter provide a backdrop for understanding how nonhuman entities achieve efficacy and agency, Latour's concepts of the bifurcation of nature, 
matters of concern, and spokespersons identify possible avenues for including nonhuman entities in our politics.

\section{Latour's Parliament of Things: The Bifurcation of Nature, Matters of Concern, and}

\section{Spokespersons}

Latour's $(2014 ; 2004)$ account of a 'parliament of things' provides a framework for ending what he calls the 'bifurcation' between facts and values that constrains efforts to bring nonhuman entities into public discourse. Building a parliament of things involves achieving a democracy where nonhuman entities are recognized as participants in shaping collective life $(2004,54)$. Latour imagines a parliament where humans and nonhumans engage with each other through associations, much like Bennett's assemblages explained above. Ultimately, there can be no bifurcation between humans and nonhumans if both are continuously affecting and being affected by one another. Latour's concept of "matters of concern"—which he substitutes for "matters of fact" - works to bring nonhuman entities that affect us through their actions, into a parliament of things through "due process." For nonhuman entities to enter our politics as matters of concern and to effectively end the bifurcation of nature, we will need what Latour calls 'spokespersons' for nonhuman entities.

For Latour, the bifurcation of nature separates matters of fact from questions of value. On the one hand, it supposes that there is a factual reality that we can get to know through our science, a reality that involves an ontology of things. On the other hand, it supposes that human values play a role in prioritizing what is important for collective life. In a bifurcated nature, values do not inform facts, and we are not conscious of the ways in which values and human interventions influence our supposed facts. In this way, human experience becomes isolated from nonhuman things and 'nature,' with human experience appearing as processes of value and our 
understanding of nonhuman entities appearing as factual realities that we come to know through our science. Latour (2014) cites Alfred N. Whitehead to help unpack the bifurcation between ontological facts and human experience. Whitehead describes the bifurcated image that isolates human experience from the activities of nonhuman entities:

Bodies are perceived as with qualities which in reality do not belong to them, qualities which in fact are purely the offspring of the mind. Thus nature gets credit which should in truth be reserved for ourselves; the rose for its scent; the nightingale for his song; and the sun for his radiance. The poets are entirely mistaken. They should address their lyrics to themselves, and should turn them into odes of self-congratulation on the excellence of the human mind. Nature is a dull affair, soundless, scentless, colorless; merely the hurrying of material, endlessly, meaninglessly (Latour 2014, 93; Whitehead, SMW, 54). Latour and Whitehead both reject the bifurcation of nature in which meaning is created through a human perspective isolated from the world it interprets. Instead, we must merge human experience and factual knowledge of nonhuman things to generate a clearer picture of how humans and things interact and affect each other. If we do not take these associations into account, we are left only with the choice between "either the meaninglessness of the senseless but real nature or the meaninglessness of the meaningful but unreal values" (2014, 95). Latour rejects the bifurcation of nature and envisages a collective life that does not disregard values or experience for the sake of facts. Facts and values are both necessary for highlighting the processes whereby matters of concern appear, and include both human and nonhuman actants. According to Latour (2004), we must rethink the way in which we conduct physical science because it does not provide us with a complete narrative, i.e. one which includes the procedures and interactions that link humans and nonhumans. Latour clarifies this point: 
As soon as we add to dinosaurs their paleontologists, to particles their accelerators, to ecosystems their monitoring instruments, to energy systems their standards, and the hypothesis on the basis of which calculations are made, to the ozone holes their meteorologists and their chemists, we have already ceased entirely to speak of nature; instead, we are speaking of what is produced, constructed, decided, defined, in a learned City whose ecology is almost as complex as that of the world it is coming to know (35). Building a parliament of things through a democracy of humans and nonhumans, helps to ensure that we are not merely defining what 'nature' is through our science, but that we take into account the procedures, hypotheses, machines, and other instruments that all work together to construct our collective life. Latour outlines the importance of appealing to matters of concern over matters of fact, as matters of concern allow us to "consult with objects" when necessary and respond to them accordingly (170).

Because it is difficult to consult with all nonhuman entities, Latour presents a compelling case for a "collective experimentation process" which allows us to consult with nonhuman things insofar as they affect humans. Consultation is a process of contestation as there are different perspectives from which we can understand how nonhuman entities affect and interact with our human societies. Latour's "collective experimentation" process takes the agency of nonhuman actants into account and involves assemblages between humans and nonhumans much like Bennett's vital materiality. He defines collective experimentation as follows:

When it is no longer possible to define a single nature and multiple cultures, the collective has to explore the question of the number of entities to be taken into account and integrated, through a groping process whose protocol is defined by the power to follow up. From the word "experimentation" as it is used in the sciences, I borrow the 
following: it is instrument-based, rare, difficult to reproduce, always contested; and it presents itself as a costly trial whose result has to be decoded $(2004,238)$.

Latour is describing the inclusion of nonhuman entities in a democratic practice where the actions of nonhuman entities appear as matters of concern to people rather than as independent facts. There are two important features of matters of concern that are important to point out.

First, matters of concern are not to be confused with matters of fact as they appear and disappear from collective life and are not to be viewed as a concrete, or inactive state of things. Indeed, Latour cautions that matters of fact can become dangerous for collective life:

The use of the term 'fact' without further precautions to designate one of the territories outlined by the frontier between facts and values completely obscures the immense diversity of scientific activity and obliges all facts, in every stage of their production, to become fixed, as if they had already reached their definitive state $(2004,96)$.

Latour is describing what is left out when matters of fact are relied upon to articulate problems that arise for collective life. Facts, when taken by themselves, tend to obscure the process by which they have been generated, i.e. the scientific work and tools used to fabricate a particular object of knowledge and site of action. Further, facts leave no room for values although it is values that designate the trajectory of facts. These "territories outlined by the frontier between facts and values" are what we must pay attention to (96). That is, what is of concern to collective life is what gets explored in the first place, and even then, we must be cautious that our facts do not get in the way of how interactions between humans and nonhumans fluctuate. Matters of fact are settled and irrefutable, whereas, matters of concern are controversial and take under consideration the variable ways humans and nonhuman entities affect and are affected by one another. In other words, because a matter of concern is "recalcitrant does not in any way mean 
that it is objective or certain, or even indisputable" (103). In actuality, a matter of concern "agitates, troubles, complicates, provokes speech, [and] may arouse a lively controversy" (103). Second, and relatedly, when matters of concern appear as propositions to human societies, they require a new understanding of human and nonhuman associations in which science itself must be re-articulated. Latour uses the example of prions to clarify this point. The discovery of prions as the "unconventional proteins that appear responsible for mad cow disease" became a matter of concern for collective life as the disease affected cows, people, farming practices, economies, and so on (111). It is not sufficient to turn only to biologists when dealing with issues such as prions. We must instead consult a number of parties, who are all representing different interests and perspectives. We must ask ourselves, "how can we arrange in order of importance the beef market... the slaughter caused by automobiles, the taste of vegetarians... the income of my farmer neighbors... the Nobel Prize awarded...to Professor Stanley E. Prusiner, one of the discoverers of prions?" (113). Certainly, we cannot "homogenize the voices that participated in the power to take into account" matters of concern just as we should not "homogenize those which participate in the power" to prioritize what is important for collective life (113). For Latour, understanding a matter of concern becomes more holistic when we consult with all of the human and nonhuman actants involved. This consultation process eventually leads to a more effective response, or what Latour calls 'institutional closure' - a temporary solution that best addresses the current issue.

For Latour, governing a polity that consists of human and nonhuman actants involves the process of taking matters of concern into account, putting them in order, and following-up by acting accordingly. For example, water contamination is a matter of concern, and when addressed through collective experimentation, entails that we understand the trajectories of 
human and nonhuman actants that worked together to create the issue. We can consult with stakeholders, both human and nonhuman, to understand why water contamination may have occurred for the benefit of some, but detriment to others, and we can use this knowledge to inform our decision-making. In this way, "political ecology does not shift attention from the human pole to the pole of nature; it shifts from certainty about the production of risk-free objects (with their clear separation between things and people) to uncertainty about the relations whose unintended consequences threaten to disrupt all orderings, all plans, all impacts” $(2004,25)$. Appealing to matters of concern over matters of fact helps to establish a parliament of things that overcomes the bifurcation between facts and values, bridging the divide between human and nonhuman things in the process. Instead of relying solely on matters of fact to guide our decision-making, Latour's concept of matters of concern allow us to recognize, accept, and legitimize the agency of nonhuman things, eventually allowing them to become "registered as full-fledged members of collective life" (104). While it is true that we cannot bring every nonhuman entity into a parliament of things, we can certainly include them according to the "specific problems that they raised for the collective," just as prions were articulated only after the onset of mad cow disease (169).

For Latour (2004), spokespersons are essential for including nonhuman entities as “fullfledged members of collective life" (104). He defines spokespersons as follows:

[Spokespersons are] an expression used at first to show the profound kinship between representatives of humans (in the political sense) and representatives of nonhumans (in the epistemological sense). Next, the term is used to designate all the speech impedimenta that explain the dynamics of the collective. The spokesperson is precisely the one who does not permit an assured answer to the question 'who is speaking'? (250). 
Latour's description of the kinship between human and nonhuman representatives conforms with his criticism of the fact-value dichotomy described above. After we move past matters of fact and appeal instead to matters of concern, it becomes clear that old styles of representation do not suffice in consulting with nonhuman entities and bringing them into the collective. Whereas the old designation of value was given through political discussion and fact through scientific inquiry, Latour's spokespersons collaborate between the two domains, at the same time acknowledging what they do not and cannot know. Traditionally, science and politics have been at odds with one another rather than working together to consult all relevant stakeholders:

[B]etween the speaking subject of the political tradition and the mute things of the epistemological tradition, there was always a third term, indisputable speech, a previously invisible form of political and scientific life that made it possible sometimes to transform mute things into 'speaking facts,' and sometimes to make speaking subjects mute by requiring them to bow down before nondiscussable matters of fact (68). Instead of restricting discussion, Latour's spokespersons recognize what he calls, the 'speech impedimenta,' or rather-the limits of representation that occur when they speak on behalf of other entities. Latour's description of "lab coats" helps to clarify this point.

While spokespersons from the scientific community are important for the collective, we must still question their speech and ask how it is that they generate their speech. Latour points out that, "the lab coats are the spokespersons of the nonhumans, and, as is the case with all spokespersons, we have to entertain serious but not definitive doubts about their capacity to speak in the name of those they represent" (64-65). That is, while scientific information is an invaluable tool for articulating matters of concern, it often does not reveal the entire story. Certainly, lab coats do not "speak on their own about mute things" (67). On the contrary, they 
have "invented speech prostheses that allow nonhumans to participate in the discussions of humans, when humans become perplexed about the participation of new entities in collective life" (67). We must carefully pay attention to what is lost when we employ "speech prostheses" to nonhuman entities. After all, "things become, in the laboratory, by means of instruments, relevant to what we say about them" (67). What we can do is be aware of our intervention in the process of speaking for nonhumans as our desires, interests, and cultural attitudes are intermixed with how we interpret nonhuman perspectives. In this way, spokespersons do not claim to speak directly for anybody or anything, but instead acknowledge their own shortcomings in speaking on behalf of their constituents.

Latour's collective not only redistributes "speech between humans and nonhumans, but also learns to be "skeptical of all spokespersons - those who represent humans as well as those who represent nonhumans" $(2004,232)$. Because politics and epistemology are intertwined in the collective, interests can always be modified and compromise is always an option. In this way, a spokesperson's role is not rigid, but collaborative, as they have power to "modify those whose opinion they are supposed to represent faithfully" (146). Latour's parliament of things provides a path toward a collective life in which human and nonhuman entities can all be engaged in the political process. Latour goes so far as to say that to limit "discussion to humans, their interests, their subjectivities, and their rights, will appear as strange a few years from now as having denied the right to vote of slaves, poor people, or women" (69). Latour's discussion of the bifurcation of nature, matters of concern, and spokespersons suggests that the inclusion of nonhuman entities in collective life can be beneficial for both humans and nonhumans. 


\section{Potential Political Implications of Post-Humanist Ecology}

Bennett and Latour both propose a political ecology in which we not only recognize the agency of nonhuman entities, but also include this understanding of agency in our political decision-making. Bennett asks: "Would a discursive shift from environmentalism to vital materialism enhance the prospects for a more sustainably-oriented public? $(2010,111)$. Bennett proposes that a new kind of ecologically-minded politics can develop from recognizing the efficacy and agency of nonhuman entities. Instead of promoting an environmentalism which aims to protect and preserve a distant 'nature,' vital materialism reveals the interconnection between human actors and nonhuman actants and suggests that we should not separate the two domains. In fact, vital materialism provides the groundwork for the "self of a new self-interest" by reminding us of the "very radical character of the (fractious) kinship between the human and nonhuman" (Bennett 2010, 112-113). Bennett suggests that a cultural shift can occur when we see the world through the lens of vital materialism, and this shift can inform a new ecologically sustainable politics.

Bennett compares the potential societal effects of vital materialism to Félix Guattari’s description of how 'Integrated World Capitalism' (IWC) works, indicating that our conception of nonhuman agency implicates our politics:

It is precisely because IWC works by appropriating bodily affect and channeling unconscious intensities that a greener self-culture-nature will require not only new 'laws, decrees and bureaucratic programmes' but 'new micropolitical and microsocial practices, new solidarities, a new gentleness, together with new aesthetic and new analytic practices regarding the formation of the unconscious.' (114). 
Our conceptions of nonhuman entities, and 'nature' inform our aesthetic and analytic styles. Vital materialism and post-humanist theories of ecology more broadly, tell us that we are connected to lively nonhuman entities who can and do affect us, and this knowledge can inform an ecological-mindedness which implicates our social and political practices. That is, when we conceive of ourselves as being part of 'nature' and inexorably linked to nonhuman entities, our priorities and value judgments shift not only on a personal and social level, but also on a political level. In this way, ecological problems are "as much a matter of culture-and-psyche-formation as [they are] of watershed management and air quality protection" (114).

Where Bennett envisions a post-humanist ecology that creates normative shifts within society that then influence politics, Latour's reformulation of political ecology and democracy as a 'parliament of things' focuses on the organization of the sciences and politics. By redefining the role of the sciences to speak on behalf of nonhuman human entities and incorporating their viewpoints in our politics, we can build a more ecologically-minded democracy. Bennett and Latour both envision a new environmentalism in which ecological sustainability grows from within a new conception of the human relationship with nonhuman entities. Latour asks: "if we assure ourselves that humans no longer engage in their politics without nonhumans, is this not what the 'green' movements have always sought, behind the awkward formulas involving the 'protection' or the 'preservation' of 'nature'? $(2004,226)$. When we understand ourselves through the lens of post-humanist ecology, we become aware that we are part of 'nature,' interacting with and alongside a variety of nonhuman actants. Most importantly, Bennett and Latour's ecologies tell us that sustainable ecological practices can flourish, not as an ethical responsibility to protect a 'nature' which we control and manage, but because we must protect ourselves as situated actors within it. 
Comparing Bennett and Latour's concepts with indigenous beliefs and practices reveals how cultural attitudes regarding nonhumans can influence ecological practices and politics. In the next chapter, I compare and contrast indigenous Amazonian and Maori practices and beliefs with Bennett's concept of assemblage generally and her discussion of edible matter in particular, as well as Latour's description of the bifurcation of nature, matters of concern, and spokespersons. While the indigenous people and rights of nature movements under study are not based in post-humanist thought and terminology, they make for compelling and informative cases of comparison. Furthermore, they provide key terms and concepts for legal recognitions of nonhuman entities and agents. Thus, they provide an occasion to evaluate several possible political implications of post-humanist ecologies. 


\section{CHAPTER III: INDIGENOUS BELIEFS, PRACTICES, AND POST-HUMANIST}

\section{ECOLOGIES}

Before considering the implications of post-humanist ecologies in connection with rights of nature laws, it is necessary to trace intersections with indigenous beliefs and practices from which rights of nature laws have been born in Ecuador, Bolivia, and New Zealand. Indigenous populations in Ecuador and Bolivia dwell in the overlapping Andean and Amazon Basin regions of South America. For the purposes of this paper, the term 'Amazonians' and 'indigenous peoples of Amazonia' will refer to indigenous groups who inhabit these specific regions. The comparative analyses that follow will not only be useful for interpreting how post-humanist ecologies can inform environmental practice, but will also provide a lens from which to understand the political implications of rights of nature laws in chapter four. Below, I analyze indigenous Amazonian and Maori beliefs and practices in light of concepts borrowed from Jane Bennett's (2010) 'vital materialism' and Bruno Latour's (2014) 'parliament of things.' Specifically, I compare indigenous Amazonian views of the body with Bennett's interpretation of assemblage, shamanic medicinal practices with her concept of edible matter, and species classification schemes with Latour's description of 'matters of concern.' Next, I compare the Maori understanding of ecosystems with Bennett's concept of assemblage and their practices involving 'mauri'—or life force—with Latour's 'matters of concern.' These comparisons will reveal how post-humanist ecologies can inform a more ecologically-minded politics as indigenous practices and beliefs exist as a "set of relays between moral contents, aestheticaffective styles, and public moods" (Bennett, xii). For Bennett and Latour, politics are implicated in our very conception of 'nature' as our understanding of nonhuman agency affects how we bring nonhuman entities into public and legal discourse. Indigenous Amazonian and Maori 
beliefs and practices reveal how ecological responsibility and guardianship might develop from a cultural positioning that gives nonhuman entities their due.

\section{Indigenous Amazonian Beliefs and Practices}

Indigenous Amazonian beliefs and practices concerning the body, shamanic healing, and species classification systems reveal a relational understanding of humans and nonhumans in which nonhuman entities are often perceived as part and parcel to community life. I discuss these practices and beliefs in terms of how they might contribute to an ecological orientation predicated on the responsibility to protect nonhuman entities as a matter of human interest and inherent guardianship. The relational conception of humans and nonhumans in Amazonia is contrary to modern, anthropocentric claims that posit human subjectivity as separate from nonhuman things. Whereas modern understandings of human and nonhuman associations view relations as secondary qualities, indigenous Amazonians view these relationships as constituting the actual entities involved. When humans are viewed as distinct from other entities, it encourages domination and exploitation over 'nature' and its resources. Amazonians, however, have a predisposition toward the protection of 'nature' because their identities and cultural practices are based in human and nonhuman interactions. While conceptions of the body, communal healing practices, and species classification all exhibit a relational conception of human and nonhuman entities analogous to that described by Bennett and Latour, species classification will reveal potential differences concerning the processes by which nonhumans enter politics as 'matters of concern' in the indigenous context.

\section{Corporality and Assemblages}

As detailed in chapter one, assemblages involve human and nonhuman actants who affect and are affected by one another, often through dynamic process and relationships. In this 
scenario, agency is distributed across many bodies and forces, governed by a relational context in which human and nonhuman things frequently engage with each another. Indigenous Amazonian views of the body provide an example of how a conception of distributive agency can implicate human practices and beliefs. In what follows, I examine how the Wari people of Bolivia interpret the body in terms of its relational and transformative properties.

What I find most interesting about the Wari conception of the body is that for them, the body is in a constant state of metamorphosis, depending upon its interactions. Aparecida Vilaca (2005) points out that "Amazonian ethnographies have shown how the body is slowly and continuously fabricated in a constant flow involving nutrition, abstention, the application of medicines, body painting, baptismal rituals, and formal training" (447). There is no single or static definition for what the body is in Wari culture. The Wari concepts of 'kwere' and 'jam' reveal how the Wari imagine a body as an assemblage rather than a static and individual entityone constituted through its relationships with other, sometimes nonhuman, entities.

Although 'kwere' translates to English as 'body,' it has very different connotations in Wari culture. According to Vilaca (2005), the Wari body is constituted by affects and memories rather than independent and continuous physical properties. In fact, memory is "located in the body, meaning the constitution of kin is based to a high degree on living alongside each other day-to-day and on reciprocally bestowed acts of affection and care." (Vilaca, 449). It is not along biological lines that the Wari understand the body but through various interactions that affect and change it. In this way, kwere is a disposition, implying a "more specific mode of acting and "set of affections or ways of being rather than a physical substrate" (Vilaca, 450). The link between memory and kinship exemplifies these "set of affections" as memory is constituted in individual experience, indicating that lines of kinship are contingent upon the unique relationships that 
entities share. Likewise, kwere is not a "substance impregnated with dispositions and affects," but rather a "way of being actualized in bodily form" (Vilaca, 451). In this way, the body is not a starting point, but is fabricated based on "the negation of the possibilities of the non-human body" (Vilaca, 451). That is, an entity is defined by the behaviors of other entities that act upon and engage with it. These 'modes of acting' are not limited to humans as "things, like persons, are constituted within relations" with kwere "appearing as the outcome of the latter" (Vilaca, 456). Viveiros de Castro (2002) points out how this state of flux can be somewhat unnerving when determining lines of kinship:

Metamorphosis is something that haunts the native imagination. Hence, although making kinship is a way of ensuring forms, if we consider that kin are made out of others, there always exists a latent possibility of alteration - that is, of kin revealing themselves to be as they were or as they really are. Alterity, not identity, is the default state in Amazonia (391).

While a grandfather might be considered a grandfather to a particular person due to close proximity and affectionate care as detailed above, that same person may have been grandfather to several other people or will be at different times depending on circumstance, not genealogical record. When lines of kinship and identify are perceived as malleable, they fit more readily into Bennett and Deleuze's description of affective bodies, with the only constant in both cases being the potential for transformation.

Vilaca's description of kwere and de Castro's example of kinship is echoed in Bennett's description of "affective bodies" interacting in an assemblage. The body understood as kwere, is neither a subject or object, but as Bennett insists, a mode which can "mod(e)ify and be modified by others" (23). The modifying capacity of affective bodies to affect others and be affected in 
turn is comparable to the Wari conception of memory and kinship. Memory is created through affective relationships which compose an individual's experience and form one's disposition. In this case, memory is a substrate of lines of kinship in Wari culture as it is through past experiences of interaction that familial lines are drawn.

For the Wari people, rocks, stones, water, animals, and even wind can all possess their own unique dispositions and affective capacities (Vilaca, 448). What differentiates one bodily form from another is therefore measured by how it engages with other bodies, both human and nonhuman. Descola (1996) points out the similarities between how humans and nonhumans are conceived in Amazonia:

The nature-culture dichotomy [is] an inadequate or misleading tool to account for the ways in which the people... [talk] about and interact with their physical environment... Not only do they [indigenous peoples of Amazonia] commonly attribute human dispositions and behaviours to plants and animals - but they also expand the realm of what are, for us, non-human living organisms to include spirits, monsters, artefacts, minerals or any entity endowed with defining properties such as conscience, a soul, a capacity to communicate, mortality, the ability to grow, a social conduct, a moral code, etc. (82).

The anthropomorphizing of nonhumans is not surprising considering that indigenous Amazonians define entities based on their relationships to one another rather than on physical or biological properties. Marilyn Strathern (1999) helps clarify this point:

$[\mathrm{H}]$ umanity, and thus a division between humans and others, is not the principal ontological axis. I do not think that the difference between 'spirit' and 'animal' or 'human' has been the archetype for perspectival traffic in the Amazonian sense. Rather, it 
is persons who offer perspectives on one another. By this I mean that the significant lines are internal, between beings as distinctive social entities, that is, between types or kinds, distinguished by their relationships with one another (252).

The "types or kinds" of relationships Strathern is referring to are what set entities apart from one another. Entities are not identified by clearly defined bodies, such as nonhuman animal, thing, or human, but rather by relationships that affect their dispositions. Thus, bodily form appears as an effect of processes of interaction, not as a precursor to them. For example, Amazonians might designate a rock as a tool, but they are aware that the same rock might be building material for birds, or a valuable component in soil and river systems. In this way, bodies are understood not only by their physical qualities, but also by their different experiences, much as lines of kinship are determined. Just as lines of kinship are drawn differently depending upon specific affective relationships, nonhuman entities can also be defined according to other sets of affective potentials in the assemblages of which they are part.

Humans and nonhumans are not considered separate and distinct entities within Amazonian cultures, but are instead understood through the perspective of the observer. That is, who is watching dictates what an entity is. For example, the Wari know that "what blood is depends on who is looking... for jaguars, for example, blood is beer." (Vilaca, 457). The identity of entities is understood through the Wari concept of 'jam' which 'implies the capacity to 'jamu', a verb which means to transform, especially in the sense of extraordinary action" (Vilaca, 452). Jamu indicates a capacity to "adopt other habits, thus enabling the [entity] to be perceived as a similar by other types of beings" (Vilaca, 452). The transformational quality of jamu can be interpreted as the interplay between actants, where human and nonhuman participants are in a constant state of dynamic interactions in which action by one member may 
not only change the course of another entity, but may actually change its very nature. Indeed, as Vilaca points out, "transformation may always be the result of the agency of other subjects rather than ego's desire" (453). In this view, one can never be sure what a human or nonhuman thing $i s$ completely, as its relational capacities are never fully exhausted.

Classifying human and nonhumans from the perspective of their engagements with other entities can help us move away from our human-centeredness, which may be alarming and uncomfortable, but also practical. When we take into account the perspectives of nonhuman entities, we alert ourselves to events that may have been unforeseen through a solely human lens and produce more proactive policies as a result. Further, Bennett's discussion of anthropomorphism tells us that relational views allow us to perceive affinities between humans and nonhumans which can engender care and sympathy. In Wari culture, there is a sense of personal responsibility to protect nonhuman entities as they are inherently tied-in with humans through their interaction in assemblages. While humans may not perceive their blood as being beer, it is important to remain cognizant of how we are situated among various other entities, each with different needs and trajectories of action, that can and do affect us. Conversely, jaguars do not know what beer is, and do not literally perceive blood as beer in the human sense, but this anthropomorphizing of the jaguar's experience is crucial in recognizing the interconnectedness of human and nonhuman entities. Bennett explains the importance of anthropomorphism at length:

In a vital materialism, an anthropomorphic element in perception can uncover a whole world of resonances and resemblances - sounds and sights that echo and bounce far more than would be possible were the universe to have a hierarchal structure. We at first may see only a world in our own image, but what appears next is a swarm of 'talented' and 
vibrant materialities (including the seeing self). A touch of anthropomorphism, then, can catalyze a sensibility that finds a world filled not with ontologically distinct categories of beings (subjects and objects) but with variously composed materialities that form confederations. In revealing similarities across categorical divides and lighting up structural parallels between material forms in 'nature' and those in 'culture,' anthropomorphism can reveal isomorphisms (99).

In Bennett's view, anthropomorphizing provides a conceptual tool that enables us to perceive the experience of nonhumans as similar to those of humans. From this vantage point, we can begin to create a more ecologically-minded politics. If we attribute human qualities to nonhuman things we can begin to see ourselves outside of our supposed uniquely subjective human experience while instilling a sense of equality between people and things. Nonhumans, recognized as actors in themselves, and as vital participants in identity formation, further promote a flattening out between humans and nonhumans that can create an ecologically aware disposition. When we perceive ourselves as similar to rather than distant from nonhuman entities, we are in a better position to care for the well-being of 'nature' which we all inhabit and to view ecological issues from a more than human lens.

The Wari concepts of 'kwere' and 'jam' exemplify Bennett's political goal of creating a "polity with more channels of communication between members" (141). The way in which the Wari people understand kinship and human and nonhuman bodily forms takes into account lines of communication between entities to the extent that these relationships form their identities. Indeed, Bennett's call for "action and responsibility that crosses the human-nonhuman divide," consistently plays out in Wari culture $(2010,24)$. For the Wari, one cannot label a human or nonhuman without understanding the ways in which they affect and are affected by other 
entities. Their conception of the body opens up new avenues for consideration regarding the human responsibility to protect the life and well-being of nonhuman entities. If human action and identity are understood through their entanglements with nonhuman agents, it is in the human interest to protect the integrity of all those things that constitute our identity. Ecological protection takes on a different form of responsibility in this case. Instead of acting as separate agents and protecting an indirect and distant 'nature,' indigenous Amazonians conceive of themselves as part of a larger ecological assemblage from which they cannot detach themselves. In this way, ecological protection can be directly linked to human experience and day to day life. Shamanic practices throughout Amazonia further demonstrate the interplay between humans and nonhuman actants. These practices point to a distributive agency in which plants act through and alongside humans in community healing performances.

\section{Plants, Shamanism, and Edible Matter}

In Amazonia, medicinal knowledge is passed down over centuries through oral tradition. However, shamans still spend much of their lives studying the spiritual and physical properties of plants (Bussmann and Sharon 2006). The shamans, or 'curanderos' of southern Ecuador serve as spiritual leaders as well as healers and are believed to channel the healing properties of different medicinal plants (Beyer 2010). Because plants and animals are ascribed the status of persons, "they are believed to see themselves in human form and thought to be self-aware of their own personhood" (Beyer, 113). This point is important when studying plants as vital materialities in Amazonia, as plants are believed to quite literally speak to shamans, teaching them how to heal specific ailments. Like Bennett, shamans understand that edible matter can affect one's habits and dispositions. However, they understand the vitality and efficacy of plants somewhat differently. While edible matter acts through humans, affecting their dispositions in 
both the shamanic tradition and Bennett's description, shamans understand this process as part of their education rather than through scientific processes. For Bennett, the vital materiality of nonhuman entities is not a "spiritual supplement or "life force" (xiii). Instead, she equates "affect with materiality, rather than posit[ing] a separate force that can enter and animate a physical body" (xiii). I explore indigenous conceptions of the vital materiality of plants in terms of how the physical properties of plants couple with communal healing practices to create a specific ecological imaginary in Amazonia.

While Bennett draws on scientific studies of chemical compounds in plants that cause hallucinations, shamans believe plants possess a spiritual and communicative power that allows them to connect to other human and nonhuman things. Curanderos believe plants are teachers as their physical and spiritual properties work to heal and alter psychological states. For curanderos, plant knowledge is typically gained through a special diet consisting of the plants under study or through a spiritual process guided by ingesting plants with hallucinogenic properties such as ayahuasca. In this way, "to learn the plants, you do not just diet; you diet with a plant—-that is, ingest the plant take it into your body, let it teach you from within while you keep loyal to it" (Beyer, 60). Curanderos recognize plants as possessing human-like qualities, and once ingested, plants are able to speak through them. This interaction becomes possible as curanderos are thought to be a medium through which plant knowledge is transferred, much like a dialogue takes place between persons. As Beyer (2010) points out, this tends to be an intimate process: The shaman 'masters' the plant by taking the plant inside the body, letting the plant teach its mysteries, giving the self over to the power of the plant. There is a complex reciprocal, interpersonal relationship between shaman and other-than-human person-fear, awe, passion, surrender, friendship, and love (61). 
In this way, curanderos understand themselves as apprentices to the plants which they study (Beyer, 62). Where Bennett's edible matter, such as the lipids in certain snack foods or omega-3 fatty acids in fish, can cause external changes like weight gain or mental changes such as lowered propensity to violence, curandero practices indicate that plants not only physically act as agents within the body, but they also serve a more profound role as teachers for the health of the entire community (Beyer, 64). In this view, it is plants themselves who dictate how and why they are used in practice.

This viewpoint is in line with Bennett's description of the 'vital materiality' of nonhuman things. For Bennett, nonhuman things ought to be understood as personified actors - as lively materialities that can "enliven or destroy, enrich or disable, ennoble or degrade us, [and] in any case, call for our attentiveness, or even respect" (ix). Shamans and indigenous Amazonians believe that nonhuman entities are very much alive and predicate their healing practices on this notion. Bennett's goal of articulating the "vibrant materiality that runs alongside and inside humans to see how analyses of political events might change if we gave the force of things their due" is already taking shape throughout Amazonia (viii). Although Bennett wants us to recognize how we are affected by vibrant materialities in a non-spiritual, scientific sense, the mystical way in which Amazonians interpret vibrant materialities also creates public moods and dispositions that implicate political practices. Amazonians bring nonhumans into the political realm through different tools, instruments, and practices. For Amazonians, "giving the force of things their due" does not only mean studying their physical properties, but acknowledging them as equal agents and essential participants in community life.

Shamanic spiritual practices with plants involve healing rituals that are tied in with specific types of music and dance traditions. The ritual of ayahuasca is a common "thread linking 
the religion and spirituality of almost all the indigenous peoples of the Upper Amazon" (Beyer, 210). Usually ingested as a drink, ayahuasca is readily available in most parts of Amazonia. It is through the hallucinogenic power of the ayahuasca drink that "hundreds of healing plants, including the plants used for magical attack and defense, reveal their appearance and teach their songs" (210). Plant 'songs' are an important feature of this experience, with different varieties of plants believed to possess their own vibratory qualities, which are then performed by curanderos and their communities through song and dance (Beyer, 80).

Bennett points out that edible matter has long been recognized in European philosophical traditions as playing an important role in cultural practices that have shaped the "dispositions of persons and nations" (43). She quotes Nietzsche's example of Bismark's Germany to illustrate this point:

Nietzsche gestures toward the agency of the food-person-sound-nation assemblage in his discussion of anti-Semitism's hold on Bismarck's Germany: he names beer as a contributing source, but beer as part of a diet consisting also of German "newspapers, politics... and Wagnerian music' (44-45).

Nietzsche's view of edible matter as part of a larger societal assemblage is very much inline with traditional curandero practices as they both involve much more than the ingestion of a specific substance. Instead, these types of assemblages implicate other cultural practices, which imbue certain edible materialities with agentic potentials they might not otherwise have. In the case of Bismark's Germany, anti-Semitism was constructed not by one, but by many concurrent practices. Likewise, shamanic learning and healing does not take place in Amazonia merely by ingesting certain plants, but with the help of other social and cultural forces. Western science, however, tells us that hallucinogenic plants such as ayahuasca and even tobacco, do possess 
chemical elements that can affect one's disposition, habits, and health on their own. Therefore, it is not just the cultural and spiritual significance of plants that determine their public effects, but also the physical properties of the plants themselves.

In particular, chemists have found that ayahuasca contains the MAO-A inhibiter known as B-carboline, a chemical compound known for its hallucinogenic properties (Beyer, 209). Hallucinogenic compounds can alter one's physical and mental state in such a way that disposition and mood are strongly affected. This is also true of tobacco, which is used as a healing plant in many cultures throughout the upper Amazon. Tobacco can be "smoked, snuffed, chewed, licked, or even made into a syrup" for recreational use and healing purposes (Beyer, 269). In fact, "mapacho is a species of tobacco containing very high levels of nicotine and other psychoactive pyridine alkaloids - the highest nicotine levels of any tobacco species" in the world (Beyer, 268). Such high levels of nicotine have hallucinogenic properties and are used by shamans as learning tools and for healing practices. Although tobacco use has been proven to have negative consequences on health, there are studies that also suggest nicotine can help to "counteract the depression of performance produced by scopolamine on both rapid information and complex processing tasks" (Beyer, 269). Further, tobacco has been linked with improvement in "general psychopathology symptoms, poor attention, disorientation, [and] poor impulse control (Beyer, 269).

Although Bennett does not suggest that edible matter has efficacy through spiritual properties, it is clear that one's perception of spiritual efficacy does have lasting political effects in indigenous Amazonian culture. Where science dictates the function and implications of chemical compounds within plants, it is also their spiritual significance, role as teachers, and accompanying communal practices that dictate their complete function in Amazonian society. 
Moreover, although shamans are the only ones to receive plant knowledge, healing is very much a communal practice in Amazonia as everyone plays an active role in the health and well-being of others. This community-oriented practice of healing may not only intensify the physical effects of plants, but can also inform how indigenous Amazonians care for plants and other nonhuman entities as the groundwork for societal-level guardianship and responsibility to protect nonhuman entities is already established. Further, because plants are thought to be teachers, they are also community-level participants which directly links their welfare to the welfare of society. Although a thorough scientific understanding of plants is not needed to create the indigenous ecological imaginary, science does play an important role in Latour's 'parliament of things.' Below, I compare 'matters of concern' to Amazonian species classification schemes.

\section{Species Classification and Matters of Concern}

Latour proposes that nonhuman entities should be brought into collective life through their designation as 'matters of concern,' that provoke a lively controversy. He suggests that nonhuman entities engage with and affect humans through a process of collective experimentation. In this process, scientists collaborate in politics - it is scientists who consult with nonhuman entities, using their expertise to define the problems that matters of concern pose for the collective - and it is in their role as spokespersons that they collaborate with politicians through contestation and parliamentary debate. In this process, nonhuman entities become participants in collective life, and we become aware of their agency and relationship to humans. While Amazonians classify nonhuman entities in terms of their importance for humans and problems they raise for collective life, they do not employ the collective experimentation process Latour envisions. As discussed in the previous section, lines of kinship and healing practices in Amazonia reveal a relational understanding of the ways in which humans and nonhumans 
interact. Although species classification systems also involve an understating of the affective relationships between humans and nonhumans, these relationships are not studied by designated experts and negotiated through spokespersons as described by Latour. I explore here how this relational understanding couples with indigenous knowledge of the physical properties of plants and animals, exhibiting some facets of Latour's matters of concern, while rendering others, such as well-defined experts and spokespersons, obsolete. This analysis will be important for determining the political implications of post-humanist ecologies as they move from the domain of indigenous beliefs and practices to western-centered legal frameworks in the next chapter.

Indigenous Amazonians do not classify plants and animals in terms of genetic factors as with scientific species classification schemes, but rather by their morphology and relationship to humans, in a process William Balée (2003) refers to as 'overdifferentiation.' For example, the domestic tuber crop, known as manioc, is identified as only one species scientifically, but "is typically subdivided into between 15 and 137 different folk species in Amazonian cultures... the average being 22 per native language" (Balée, 278). Moreover, the Achuar people of the Andes region recognize 12 "folk species of felines, but fewer than half of these folk species are distinguished as separate taxa in systematic zoology" (Balée, 278). The physical properties and effects of plants often dictate their specific relationship to humans and how they are brought into decision-making processes, typically through traditional knowledge and observation. In this case, 'overdifferentiation' can be interpreted as the result of consultation processes between human and nonhuman entities.

The physical properties of plants are often based in differences of appearance and gender. Leaf shape, texture and bloom color can all work to determine whether a plant is classified as male or female and dictates how it should be used in practice (Balée 2003). Plants that are 
classified by western science as the same species are named and used differently in medicinal and dietary practice in Amazonia (Beyer 2009, 307). Beyer helps to explain several of these applications:

Toé negro and toé blanco, white and black toé, are considered by botanists to be in completely different genera, but are conceptually linked through their uses and effects; ishanga blanca and ishanga roja, white and red ishanga, in different genera but both with stinging hairs used to treat snakebite; or verbena blanca and verbena negra, in different genera, but both considered to be cold plants to treat hot conditions such as fever and diarrhea (312).

It is through direct observation of the physical characteristics of plants and their consequent effects on the body that they come to be classified in Amazonia. This relational understanding is similar to Bennett and Deleuze's description of "affective bodies" as it is through their outward effects that plants are classified. However, it is different than the scientific process described by Latour in which nonhumans are a subject of perplexity and consulted with during a collective experimentation process. Instead, plants enter into collective life through generational knowledge in which many community members take part. Consultation does not happen in laboratories and there are no 'scientific' instruments and procedures that help inform how humans are to speak on behalf of nonhuman entities. Amazonia is unique in this way, as community members live in close connection with and proximity to nonhuman entities. In western society, there is a bifurcation between humans and nonhumans and assemblages between entities are not automatically apparent. That is, facts occur in laboratories and values in the political realm in western society, with no culturally embedded understanding of direct affective relationships between humans and nonhumans. However, in Amazonia, there is a deep communal knowledge 
of affective relationships stemming from direct observation and communal necessity. The classification of bees by the Kayapó people provides insight into this relational and generational type of knowledge.

The Kayapó people of Amazonia recognize over 56 different folk species of bees, of which 11 "were found to be either unknown or new to science" (Balée, 279). Bees are very important to the Kayopó way of life as their wax is used "to caulk boats, coat cotton string and cord, to make numerous ceremonial objects, and are burned to produce smoke that repels insects, exorcise evil spirits, and cure illnesses" (Posey 1983, 155). Bees are classified depending on their functional context, nest structure, location, behavior, sting, and quality of the honey they produce:

One functional classification system is based on the aggressive behavior of bees when disturbed. There are four major divisions of behavior in this system: docile, stinging, biting, and blister-causing. Another functional taxonomic system is based on honeyrelated variables: taste, acidity, quantity found in one nest, and time of the year the nest can be raided... The Kayapó recognize eight ecological zones and associate certain species of bees with each zone. Nests are grouped by: nest site (in a tree, in the earth, in vines, in abandoned termite hills, etc.); the height of the nest from the ground; the shape and size of the entrance tube (length, shape, markings, size, etc.); and nest size (based on gross size, relative amount of honey per nest, etc. (Posey, 156).

In this way, it is because bees relate to one's livelihood, tools and even diet, that they come to be a matter of concern for the Kayopó.

It is imperative that the Kayopó classify bees by their behavior, nest structure, and location, as these characteristics often dictate how humans identify useful and potentially 
harmful bees in the wild. This overdifferentiation of bees is corresponds with Latour's description of matters of concern inasmuch as the Kayopó prioritize them based on their degree of harm and importance for people. Bee classification schemes are not arbitrary means of differentiation, but rather logical and practical tools for safely extracting honey and wax. Posey (1983) helps to clarify this point:

Nests are raided using strategies consistent with the aggressive nature of the species. For the most violent (akre), fire and smoke are used to expel the colony before the nest is opened. If the nest is high up in a tree, the entire tree will be felled in order to get to the nest. For less aggressive species (wajobare), the Indians tackle the nest with axes and bare hands despite clouds of furious, swarming insects (156).

Certainly, not every insect in Amazonia is classified according to these same rules as different relationships between nonhuman plants, animals, insects, and humans require their own set of guidelines. Bee classification schemes provide a way of prioritizing, labeling and bringing bees into collective life, but there is no apparent necessity within Amazonian communities to delegate scientists and spokespersons to collaborate with political decision-makers as classification of nonhumans has become a procedure tasked to entire communities over generations. In this way, there are no designated bee experts, but cultural practices that implicate many community members in the consultation process.

The classification practices of nonhuman entities in Amazonia fits in well with the posthumanist concepts of assemblage and affective bodies, where humans and nonhumans interact in the everyday lives of Amazonians. In the indigenous context, 'nature' is not bifurcated between humans and nonhumans and matters of concern do not present themselves through a collective experimentation process. Instead, nonhuman entities are already inherently tied-in with 
indigenous practices, beliefs, and community life. It is when nonhuman entities must be addressed by wider society — where they are not already recognized as participants in community life - that matters of concern appear necessitate spokespersons and scientific processes. While the Maori do not completely adhere to Latour's collective experimentation process either, their assessment of ecosystem health does appear to be more inline with its main tenets.

\section{Maori Beliefs and Practices}

The Maori people of New Zealand share a similar ecological imaginary to indigenous peoples throughout Ecuador and Bolivia. For the Maori, humans and nonhuman plants, animals, and things are all thought to be essential parts of an overall ecosystem (TeAhukaramū 2007). Below, I compare the Maori understanding of ecosystems to an assemblage, unpacking the notion of 'whakapapa' involved in Maori burial practices and 'kaitiakitanga' as it informs sustainable land and resource management. Next, I analyze the Maori assessment of ecosystem health in light of Latour's matters of concern and collective experimentation process as it exemplifies how cultural practices can merge with scientific experimentation to reveal a new conception of agency. Maori beliefs not only indicate a conception of 'nature' that is different from western practices, I argue, but they also reflect several of the potential benefits of posthumanist ecology as outlined by Bennett and Latour.

\section{Ecosystems and Assemblages}

To unpack the Maori interpretation of ecosystems, it is necessary to understand the significance of the terms 'whakapapa' and 'kaitiakitanga.' According to Harmsworth and Awatere (2013), whakapapa is a "connection, lineage, or genealogy" between humans and nonhumans, including "all flora and fauna" (275). For the Maori, everything within the natural environment is thought to be connected to everything else, "in an intricate web of cause and 
effect," indicating a relational understanding of human and nonhuman entities (Harmsworth and Awatere 2013, 275). Kaitiakitanga is tied-in with whakapapa and is often interpreted as a form of 'guardianship' or duty to maintain a balance between all things within an ecosystem

(Harmsworth and Awatere 2013; Kawharu 2000; TeAhukaramū 2007). Bennett, recall, argues that an ethical imperative of guardianship is one of the potential benefits of post-humanist ecology. It is because the Maori first acknowledge a common thread linking humans and nonhumans in whakapapa that they engage in the guardianship of nonhuman entities in terms of kaitiakitanga. In this way, guardianship is predicated on the notion that ecosystems require the protection of all their various parts - both human and nonhuman - if they are to function properly.

Because whakapapa involves all known entities including "plants, animals, birds, fish, microorganisms, the genes they contain, and the larger ecosystems they form," the Maori are careful not to disrupt what they consider to be a natural balance within their environment. (Harmsworth and Awatere 2013, 277). Maori burial practices provide a good example of how the Maori endeavor to maintain this natural balance. Often, the burial of a Maori individual takes place closest to where he or she lived, not due to familial proximity, but because the proximity of that person to the ecosystem from which they were part (Kawharu 2000). For the Maori, the body must return to and give back to the land that sustained it throughout its life. Ancestral lines connect humans as well as nonhumans because the human body is inextricable from its environment.

The belief of an interconnection between humans and nonhumans within an ecosystem informs how landmarks are named according to their connection with the Maori people. That is, human names are attributed to specific landmarks, indicating where Maori ancestors lived, died, 
and were most connected to the land. Merata Kawharu (2000) points out some of the most notable titles:

Te Paneohoroiwi 'The Head of Horoiwi', refers to the eastern headland by the Tamaki River and so named by Horoiwi, an ancestor of the Tainui tribe. Orakei, otherwise known as Orakeiiriora, is 'The Place of Rakeiiriora'; Rakeiiriora was a leader from the Tokomaru canoe who lived in Tamaki for some time (364).

Burial practices and the naming of landmarks in Maori culture points to a deep understanding of the ways in which humans and nonhumans interact with and affect one another when participating in an ecosystem. The practice of naming landmarks after Maori ancestors is symbolic of the ways in which the Maori live off the land and interact with natural processes while striving to maintain a symbiotic relationship between humans and 'nature.'

The conception of symbiotic human and nonhuman associations is demonstrated in the Maori practices of kaitiakitanga. Although kaitiakitanga translates as 'guardianship' it can also be interpreted to mean a way of living in accordance with whakapapa (TeAhukaramū 2007). Guardianship in this sense refers to customary practices that involve resource management. Charles TeAhukaramū (2007) outlines several of these practices:

Kaitiakitanga [involves] temporary bans (rāhui) on taking food from an area, using the lunar calendar (maramataka) to decide when to plant and harvest, taking resources only as needed, hunting and fishing only for food (not as sport), using bird snares at the right time [and] not when the birds are breeding (2).

The Maori have been practicing kaitiakitanga customary ways of life for centuries, treating natural resources as vital components of a larger web of life. In fact, as their burial practices indicate, the Maori believe that natural resources - whether animals, plants, or inorganic 
materials - represent traces of their ancestry in the same way that living humans do (TeAhukaramū 2007). Thus, people are not conceived as "superior to the natural order" but are part of a "nexus that permeates all spiritual and environmental spheres" (Merata 2000, 351). For the Maori, resource management is not just a means for sustaining human survival, but a way to preserve the historical link tracing back to their first ancestors. As human and nonhuman matter decomposes in the soil and generates new life, it recycles back into the ecosystem in a cyclical process of rebirth (Merata 2000). All vital materiality thus becomes part of one ancestral lineage.

The belief in whakapapa and practice of kaitiakitanga indicate that the Maori people understand affective relationships between humans and nonhumans and that each vital materiality is essential to an ecosystem's functioning. Envisaging linkages between humans and nonhumans is important as it can potentially change the way nonhuman agency is perceived and how humans produce political effects. Kaitiakitanga and whakapapa both emphasize not only the vital materiality of nonhumans when engaged in an ecosystem, but they also challenge the hierarchy of power and agency that places human action as the sole producer of effects. This viewpoint is much different than the western conception of nonhuman entities and 'nature,' where humans are dominant actors, presiding over nature rather than actively participating within it. When humans are conceived as inextricable from their environment, and vital materialities as essential actants in their symbiosis with humans, it becomes necessary and rational to protect the well-being of 'nature.' In this way, conceptions of the agency of nonhuman entities and recognition of human and nonhuman assemblages provide the groundwork to cement ecologically-minded policies into legal and political discourse.

Maori beliefs and practices exemplify in several respects what Bennett sees as the virtue of post-humanist ecology. For example, the micropractices of kaitiakitanga reduce the impact of 
human action "so as to minimize the damage or destruction of other things which [they] share existence" (Bennett 2010, 121). Further, anthropomorphism is present in the Maori worldview as people are not named after 'natural' landmarks, but vice versa. Again, Bennett does not disregard anthropocentrism, but sees it as a means by which humans can come to know and relate to nonhuman entities. Analogies between humans and nonhumans are important to a posthumanist project, as human-centered identifications of nonhumans can reveal linkages between humans and 'nature.' The Maori conception of ecosystems not only gives nonhuman entities their due, but "reshapes the self and its interests" to create a more ecologically-minded politics (Bennett 2010, 122). Moreover, these community level cultural practices and dispositions help ensure the preservation of ecosystems through everyday actions and can add up to generate a societal public mood of ecological awareness. It is in this societal awareness that Bennett envisions a new, more ecologically-conscious political discourse emerging. Public moods implicate other societal practices as well. In the next section I explore the Maori concept of 'mauri' and how it has merged with western scientific practices measuring ecosystem health in a process similar to Latour's collective experimentation.

\section{Ecosystem Health and Matters of Concern}

There is no bifurcation of nature in Maori society, so the inclusion of cultural values in the assessment of ecosystem health comes as no surprise. Maori ecosystem health indicators are a mix of scientific data collection and cultural awareness of what the Maori believe is 'mauri'or life energy, that is exchanged between entities. Merging the cultural belief of mauri with western scientific practices exemplifies how an understanding of assemblage and the vital materiality of nonhumans can be worked into a societal level framework for addressing matters of concern. The ultimate goal of Latour's collective experimentation process is not to attribute 
responsibility to any one actant, but to reveal the process by which an emergent totality forms, uncovering the agency of nonhuman actants along the way. Below, I discuss how the Maori use a Cultural Health Index to address matters of concern in a process similar to Latour's collective experimentation.

Mauri entails that all humans and nonhumans are spiritually connected, and implicates the way in which the Maori assess ecosystem health. Harmsworth and Awatere (2013) provide a detailed definition of mauri:

Mauri [is] an internal energy or life force derived from whakapapa, an essential essence or element sustaining all forms of life. Mauri provides life and energy to all living things, and is the binding force that links the physical to the spiritual worlds. It denotes a health and spirit, which permeates through all living and non-living things. All plants, animals, water and soil possess mauri. Damage or contamination to the environment is therefore damage to or loss of mauri (276).

For the Maori, the life force of every entity is linked to the life force of every other entity and "small shifts in the mauri of any part of the environment" can cause shifts in the health of "immediately related components which could eventually affect the whole system" (Harmsworth et al. 2011, 424). Thus, when a problem arises for the Maori community, such as algae blooms in waterways, soil degradation, disease, or natural disaster, they view the problem as impacting the entire ecosystem and do not make a clear distinction between nonhuman actants and human actors.

In 1999, the Maori developed the Cultural Health Index (CHI), a "tool to express their cultural values relating to river and stream health and customary resources in a way that could be incorporated into catchment management decisions" (Harmsworth and Awatere 2013, 276). The 
$\mathrm{CHI}$ is an environmental health assessment strategy, incorporating a scientific understanding of flora, fauna, and water quality as well as cultural estimates of the condition of heritage sites and mauri. Consequently, Maori values and knowledge are incorporated along with western models of ecosystem health and sustainability (Harmsworth and Awatere 2013, 277). The CHI provides a way to address matters of concern that affect the Maori way of life while reconciling western science with cultural attitudes and beliefs.

According to Latour, matters of concern ought to be assessed through expert level knowledge as it relates to cultural values. In this way, human needs and interventions merge with the activities of nonhuman forces to generate a thorough understanding of events. Thus, agency is not attributed solely to human actors, but couples with nonhuman forces to emerge as a totality. Bennett points out that it can be difficult to attribute responsibility to any one actant, especially when unintended events occur such as the North American blackout as discussed in chapter one (2010, 26-27). Bennett borrows Latour's description of causality, for whom "there is no object, no subject...but there are events" as we are always "slightly surprised by what [we] do" (27). The CHI effectively merges scientific assessment with Maori beliefs, indicating that cultural attitudes play a role in shaping how we address ecological issues.

For the Maori, the health of one entity within an ecosystem affects all other entities. While the traditional belief in mauri contributes to a nexus understanding of matters of concern and ecosystem health, it is also through aesthetic, artistic, educational, and scientific channels that ecosystems are valued and come to be protected in Maori society (Harvey 2006). That is, every sector of society combines to create a cultural disposition that guides decision-making regarding matters of concern such as water pollution and forest degradation. The Maori interpretation of ecosystems and measurement of ecosystem health is not predicated on human 
use-values. While western conceptions of 'nature' are often centered around the accumulation of and dominance over nonhuman entities, the Maori have fostered a way of life that rejects human superiority in favor of an ecosystem approach that includes the human as an actor, but not the only, or most important actor. Because nonhuman entities are viewed as crucial participants in ecosystem health and ecosystems are perceived as a totality rather than individually-organized parts, the conservation of all nonhuman entities become a matter of both cultural significance and common-sense practice.

There is a transformation taking place at the point where indigenous Maori values enter into western scientific practices, decision-making, and legal frameworks of action. On the one hand, Maori beliefs and practices run contrary to western practices of human superiority, instrumentality and accumulation. On the other hand, the Maori must adhere to western science and legal frameworks of action to address ecosystem concerns at the state level. We can already begin to see the virtues of post-humanist ecologies as they play out within indigenous Amazonian and Maori cultures. In the next chapter, I discuss how these attitudes and aestheticaffective styles about nonhuman entities and 'nature' translate into rights of nature laws. 


\section{CHAPTER IV: RIGHTS OF NATURE LAW IN ECUADOR, BOLIVIA, AND NEW}

\section{ZEALAND}

In chapter three, I established a link between indigenous beliefs and practices in Amazonia and New Zealand and the post-humanist ecologies of Jane Bennett and Bruno Latour. These linkages will be helpful for determining the import of indigenous worldviews in rights of nature law, revealing several of the political implications of post-humanist ecology in terms of how cultural attitudes can inform legal and political discourse. Specifically, I hope to answer the following questions: Do rights of nature laws reflect indigenous beliefs and practices and serve the kinds of politics that Bennett and Latour advocate, following from a post-humanist perspective? How do rights of nature laws promote Latour's 'parliament of things' and what do they tell us about how collective experimentation might work? And finally, what new cultural styles and public moods might rights of nature laws instill in broader society in light of what Bennett sees as the virtues of post-humanist ecology? To answer these questions, I explore rights of nature laws in Ecuador, Bolivia, and New Zealand in terms of the content of the legal frameworks and their implementation and enforcement mechanisms.

\section{Rights of Nature in Ecuador}

There is a large indigenous population in Ecuador with 7 percent being fully Amerindian and 72 percent being mestizo, with a mix of white and Amerindian ancestry (CIA Factbook 2017). With such an overwhelming portion of the population being of indigenous decent, it is not surprising that Ecuador has become a plurinational polity, in which a growing number of indigenous groups have gained representation in government. In fact, Ecuador's current president, Rafael Correa, is of indigenous Andean ancestry. Correa came to power in 2006, running his campaign on constitutional reform and promoting new ways of development counter 
to western practices of resource exploitation (Burbach 2007). The election of Correa, coupled with decades of previous environmental movements led by indigenous groups and regional activists, laid the groundwork for establishing a new Ecuadorian constitution in 2008. Akchurin (2015) proposes that the idea of rights of nature grew out of the "schematic connection between plurinationality, collective rights, and an opening of the mind on subjects related to nature, combined with the political influence of the indigenous movement in the assembly process" (954). This opening up of the political realm to indigenous peoples and rights of nature advocates created a space for alternative views of 'nature' to be incorporated in the new constitution. Environmental activists, politicians, and indigenous representatives worked together to draft the new constitution which combined "radical western ecological perspectives, politicized indigenous beliefs, and legal rights discourse" to construct a "hybrid concept that imagined and codified nature as a subject of constitutional rights" (Akchurin 2015, 960). I analyze the 2008 Ecuadorian constitution below in terms of its inclusion of indigenous beliefs and practices and its implementation and enforcement mechanisms to get to the heart of how post-humanist ecologies can work in practice, and what implications they might have for wider society.

\section{Constitution of Ecuador}

There is no doubt that the 2008 constitution reflects indigenous Amazonian conceptions regarding nonhuman entities and 'nature.' Several of the initial reports that informed the drafting of the new constitution laid out the need to incorporate indigenous beliefs and practices into legal frameworks with the intent to change the development paradigm. Indeed, there was a conscious effort by the drafters to "palliate the unforeseeable consequences that [would] result if Ecuador [were to continue] with its model of development and anthropocentric approach to the environment" (Akchurin 2015, 959). The text of the constitution reflects indigenous Amazonian 
conceptions of 'nature' in terms of recognizing nonhuman entities as persons and incorporating an assemblage-like understanding of the interconnection between human and nonhuman entities.

The opening line of Chapter I of the constitution states that "persons and people have the fundamental rights guaranteed in this Constitution and in the international human rights instruments" and "nature is subject to those rights given by this constitution and law." Further, nature is referred to in the document as 'Pachamama,' which is an indigenous Amazonian term for Mother Earth. Chapter VII of the constitution lays out the rights of Pachamama, including its right to the "integral respect for its existence and for the maintenance and regeneration of its life cycles, structure, functions and evolutionary processes" (Article 71). While the document does not go into great detail regarding the protection of specific nonhuman entities, it is radical in that it encompasses all entities. As explained in the previous chapter, nonhuman entities are an integral part of Amazonian communal life and Amazonians do not strictly distinguish between human and nonhuman bodily forms. Although the text of the constitution does not directly reflect these beliefs, it does call for the protection of indigenous "ancestral wisdom... and traditional practices...with the right to restore, promote, and protect ritual holy places, as well as plants, animals, minerals and ecosystems" (Chapter IV, Article 57.12). We know from chapter three that the Amazonian relational understanding between human and nonhuman entities encourages guardianship and protection of nonhuman entities. What the constitution leaves out, however, is strong language affirming the vitality of 'nature' in itself and the significant function of nonhuman entities in Amazonian culture.

The constitution is also vague in terms of who is to speak on behalf of 'nature,' stating only that "all persons, communities, peoples and nations can call upon public authorities to enforce the rights of nature" (Chapter VII, Article 71). Whereas Latour envisions a parliament 
that enlists spokespersons from different domains to speak for nonhuman entities in the political realm, Ecuador's constitution does not outline a specific procedural method by which ecological concerns can be measured and brought into politics. However, this has not stopped Ecuadorian citizens from appealing to rights of nature law and speaking on behalf of nonhuman entities. Assessing how rights of nature are implemented and enforced in practice will give us a better understanding of the law's strengths and shortcomings.

\section{Implementation and Enforcement}

So far, there have been ten court cases that have ruled in favor of the rights of nature as established in the Ecuadorian constitution (Kauffman and Martin 2016). The first successful case (Wheeler c. Director de la Procuraduria General Del Estado de Loja) was heard in 2011 by the Provincial Court of Justice in Loja, Ecuador in which the court upheld the right of the Vilcabamba River to maintain its vital lifecycle (Daly 2012; Colón-Ríos 2015). The case was brought by Nori Huddle and Richard Fredrick Wheeler, two landowners who represented the Vilcabamba River in court. Huddle and Wheeler argued that during a city road construction project, debris was dumped into the river, disrupting its natural flow which flooded several of its tributaries, and threatened flora and fauna in the region.

There two noteworthy outcomes that stemmed from this court case. First, the court ruled that the burden to show damage and gather scientific data is on the defendant, in this case, the city government of Loja. Second, the court made it clear that the landowners did not have to prove they were affected by the city's negligence, but only that actions by the city caused damage to the river's ecosystem itself (Kauffman and Martin 2016). The city government of Loja failed to conduct an environmental impact assessment before construction and did not properly consult with conservation specialists. Indeed, Latour stresses the importance of 
consultation with scientists, who can adequately understand matters of concern from the perspective of nonhuman entities when we bring them into our politics. While this crucial step was ignored by the city government, the court's decision that the river is a rights bearing entity in itself, solidified the rights of nature, setting precedent for future court cases. Nonetheless, winning the court case proved to be only half the battle as the lack of a proper enforcement mechanism undermined the ruling.

Although the Loja city government wrote a public apology in a local newspaper and partially cleaned up the debris, they stopped short of rehabilitating the Vilcabamba River ecosystem as ordered in the ruling. Erin Daly (2012) underscores the troubling lack of enforcement for upholding the rights of nature in practice:

Even though the right has been judicially vindicated, supporters of the plaintiffs have been compelled to hire lawyers to pursue enforcement. Unfortunately, it seems that in many lawsuits seeking to vindicate environmental rights, it is as difficult to secure enforcement of remedial orders as it is to obtain the judicial victory in the first place (63).

While it is difficult to determine if the ruling would achieve greater enforcement had the environmental impact been directly linked to an infringement on human-centered rights, there are indications that appealing to rights of nature can transform the way the judicial system interprets the vitality of ecosystems.

Since the drafting of Ecuador's new constitution in 2008, two closed court cases involving mining operations were re-opened and newly assessed in light of the rights of nature (Kauffman and Martin 2016). This tells us that there is an effort within Ecuadorian society to view environmental issues from the perspective of nonhuman entities, and to consider how the vitality of nature itself has been left out of previous discussions involving ecological 
conservation. While the reopened mining cases have yet to overturn previous rulings, they signal a shift in the way environmental issues are perceived by the courts, possibly lending more credibility to the rights of nature in the future. Continued appeal to the rights of nature will only strengthen debate about the vitality of nonhuman entities, and can perhaps create a space for normative shifts in the way 'nature' is generally perceived. Maria Akchurin (2015) remains hopeful that this is the case:

This story was not only an instance of an alternative philosophy becoming incorporated into a legal framework, but also an important case of how indigenous politics influenced nonindigenous systems of authority and created the space for a different understanding of nature/society relations to be conceptualized, described, and incorporated into the constitution, pushing the boundaries of existing ideas about rights, authority, and the state. This process also allowed for the legal materialization of broader ontological debates about the status of nature (960).

At this point, appealing to the rights of nature in Ecuador is at a preliminary and reactionary stage. Yet, as Bennett points out, there is hope for a new ecologically-minded politics that can evolve out of the understanding of nonhuman entities as vital materialities. When we shift our attention away from the old language of environmental management to new ideas about how humans are situated among various nonhuman actants, we can inform new ecological practices that are proactive from the start. For now, rights of nature laws in Ecuador seem to be laying the groundwork for a cultural shift in the way humans perceive the vitality of nonhumans in themselves.

Meanwhile, the Ecuadorian court case affirms the necessity to enlist spokespersons who consult with and speak on behalf of nonhuman entities. Relying on defendants to conduct their 
own environmental impact assessments is certainly not a viable means for ensuring an unbiased account of what is in the nonhuman's interest. For Latour, it is not just a question of whether we bring nonhuman entities into our politics, but how we can do it effectively. That is, rights of nature laws allow for the legal status of nonhuman entities, but it is important to understand the channels by which we come to know what issues they raise for collective life. With luck, collective experimentation will work itself into the political and legal system as cultural attitudes and perspectives regarding the status of nonhuman entities as vital materialities continue to change.

\section{Rights of Nature in Bolivia}

Indigenous peoples of Bolivia played an instrumental role in securing the rights of nature at the national level in 2010, following a similar path as indigenous Ecuadorians. In 2001, indigenous peoples gained recognition as a constituency within the now Plurinational Bolivian government, using their political voice to "openly challenge Eurocentric values in favor of nonmaterialist relationships with nature" (Hicks and Fabricant 2016, 93). In 2005, Bolivia elected Evo Morales, the first indigenous president of South America, who promised to challenge the neo-liberal development paradigm and embrace indigenous worldviews to help combat climate change (Hicks and Fabricant 2016). Indigenous beliefs about 'nature' began to take center stage in climate negotiations throughout Bolivia, culminating in the 2010 World People's Conference on Climate Change (WPCCC) held in Tiquipaya. The WPCCC was a pivotal moment in Bolivia's move towards adopting the rights of nature. The WPCCC brought together government representatives, indigenous and social groups, and environmental activists to develop the Universal Declaration on the Rights of Mother Earth (UDRME), a new model of development which later informed the Bolivian Law on the Rights of Mother Earth. 
The UDRME was drafted as a preemptory norm to direct "sustainable development away from the discourse of [the] green economy and to align it with rights of nature discussions" (Espinosa 2014, 410). With a focus on the interdependence between society and 'nature,' the UDRME was intended to disclose the "intimate and inextricable connections among humans, other species, ecosystems, and the planet we inhabit together" (Sheehan 2012; Espinosa 2014, 399). Accordingly, the UDRME underpins "the claim that humans are not apart from nature" and that "the organic and inorganic components of planet Earth have evolved together as a single living, self-regulating system" (Espinosa 2014, 399). The political goal of the UDRME to change the sustainable development paradigm resembles what Bennett sees as the virtue of her vital materialist project. Bennett asks: "Would a discursive shift from environmentalism to vital materialism enhance the prospects for a more sustainably-oriented public?" (111). Her comparison between environmentalism and vital materialism gets to the heart of this shift: It is difficult... for a public convened by environmentalism to include animals, vegetables, or minerals as bona fide members, for nonhumans are already named as a passive environment or perhaps a recalcitrant context for human action. A more materialist pubic would need to include more earthlings in the swarm of actants. If environmentalists are selves who live on earth, vital materialists are selves who live as earth... If environmentalism leads to the call for the protection and wise management of an ecosystem that surrounds us, a vital materialism suggests that the task is to engage more strategically with a trenchant materiality that is us as it vies with us in agentic assemblages $(2010,111)$.

There are strong similarities between a vital materialism which aims to reveal nonhuman agency and networks within assemblages and the UDRME which seeks to highlight the interdependence 
between humans, nonhumans, and Earth's systems. Not only do they both challenge western norms concerning the hierarchy of living beings and 'nature,' but they also offer an alternative approach, rooted in the notion that if we change our perspective of humanity as situated within 'nature,' then sustainable ecological practices will follow. Bolivia's Law on the Rights of Mother Earth follows the main tenets of the UDRME and further reflects the virtues of post-humanist ecology as described by Bennett and Latour.

\section{Bolivian Law on the Rights of Mother Earth}

The Law on the Rights of Mother Earth highlights the importance of 'nature' in indigenous practices as well as the significant role that different culture plays in realizing the rights of nature. As discussed in chapter three, ecological protection of 'nature' seems to flow logically from the vital role that nonhuman entities, such as plants and bees, play in communal rituals and Amazonian ways of life. Moreover, affective relationships between humans and nonhumans tend to dictate Amazonian cultural practices and are inherently tied in with identity formation. From this perspective, it is not surprising that the Law on the Rights of Mother Earth specifies that "the exercise of individual rights is limited by the exercise of collective rights in the living systems of Mother Earth" (Chapter II, Article 6). This is a radical statement as it is most often human rights that take center stage in legal discourse. Yet, when we consider this from the lens of post-humanist ecology, we can see that individual rights are contingent upon the activity of other human and nonhuman actants in an assemblage. Indigenous beliefs and posthumanist conceptions about the horizontal nature of agency make practical sense when considering how we might live sustainably as a collective. It is only when nonhuman entities are taken seriously as vital agents in collective life that we can ensure the long-term fulfillment of human rights. For example, the preservation of lakes and rivers can help ensure long-term human 
access to fish stocks and promote financial security in fishing-based economies. It follows that human and nonhuman rights ought to be mutually exclusive. While this is a radical concept in terms of western views regarding individual rights, there is room in Bolivia's law to include western practices in the realization of the rights of nature.

As also discussed in chapter three, Amazonians do not rely on western science to understand nonhuman entities as vital materialities and to debate matters of concern. However, the law recognizes both indigenous practices and western science as key requirements for exercising the rights of nature:

The exercise of the rights of Mother Earth requires the recognition, recovery, respect, protection, and dialogue of the diversity of feelings, values, knowledge, skills, practices, transcendence, transformation, science, technology and standards, of all the cultures of the world (Chapter I, Article 2.6).

While indigenous Amazonian worldviews were key in the drafting of the law, its text reveals the importance of merging indigenous beliefs with modern scientific practices for the rights of nature to be successful.

It is when indigenous practices and beliefs move from the domain of culture to westerncentered legal frameworks that they more readily align with Latour's 'parliament of things.' The Law on the Rights of Mother Earth is grounded in the notion that there should be no bifurcation between facts and values. Combining indigenous beliefs regarding the interconnection between humans and nonhumans with modern scientific practices exemplifies a crucial step in Latour's framework for including nonhumans in collective life. For Latour, we must not only understand how nonhuman actants function and affect us, but we must also decide their relative importance in different areas of our collective life. To do this, we must not "homogenize the voices" of all 
stakeholders involved (Latour 2004, 113). While the law encompasses all entities within 'nature' as part of the "collective public interest," it also states that we must "take into account the specificities and particularities of its various components" (Chapter II, Article 5). Although the law does not go into detail regarding how we might piece apart and understand entities within 'nature,' Latour's collective experimentation process provides some insight.

Latour lists four requirements for bringing nonhuman entities into public life as matters of concern: 1) they must be a subject of perplexity, 2) they must be properly consulted with and represented by relevant spokespersons, 3) they must be ranked according to their significance for society, and 4) we must adopt institutionalized measures to ensure they are properly addressed (2004, 111). The Law on the Rights of Nature touches on these four requirements. While not all nonhuman entities are an issue of immediate perplexity, the granting of broad legal rights to 'nature' as a whole is symbolic of the interconnections between all entities - connections that

must be understood if we are to properly address ecological problems. From this perspective, all entities are important to collective life and must be legally protected. What is less clear in the law, as with Ecuador's constitution, is how nonhuman entities are to be represented through a democratic consultation process.

\section{Implementation and Enforcement}

While all Bolivians are called on to implement and enforce the rights of nature in practice, the law acknowledges the need for a special representative to speak on behalf of 'nature.' Article 10 of the law calls for the creation of the Defensoría de la Madre Tierra—-the Office of the Mother Earth Ombudsman — whose "mission is to ensure the validity, promotion, distribution and compliance of the rights of Mother Earth" as established in the act. A 2012 supplement to the law further establishes that the Ombudsman's Office "will be part of the 
Plurinational Council...together with the President of the State, national assembly and representatives of social organizations, among others" (Díez Lacunza 2016, 1). Although Benecio Quispe, an environmental lawyer, was appointed as ombudsman in February 2014, he has not brought forth any cases on behalf of the rights of nature. (Chávez 2014). Instead, Quispe has focused his attention on drafting legislation to protect specific environmental sectors such as mining and waterways (Chávez 2014). In fact, no cases have been successful in appealing to the rights of nature in Bolivia since the adoption of the Law on the Rights of Mother Earth.

Many scholars and activists have speculated on the shortcomings of the law in practice and two main themes stand out (Sheehan 2015; Herold 2017). On the one hand, science is not keeping pace with new ways of thinking about 'nature.' Linda Sheehan (2015) points out that science is "still overwhelmingly reductionist, breaking down the natural world into pieces to study and manipulate" instead of considering "the Earth's ecosystems holistically as natural systems that also include people" (105). Here we can see where there might be difficulty in translating complex concepts like 'assemblages' into legal discourse. There is a disconnect between the conception of agency as inextricably linked between humans and nonhumans and scientific and political practices that seem to be stuck in old ways of environmental management discourse. Bruno Latour (2004) foresaw this dilemma:

The challenge is not to take a position in the debate that is going to make it possible to measure the respective shares of nature and society in the representations we have of them, but to modify the conception of the social and political world that serves as evidence for the social and natural sciences (34).

Latour's collective experimentation process provides a framework for modifying the 'conception of the social and political world' while simultaneously bringing scientific practices into 
democracy that better reflect a nonbifurcated nature (34). Successfully uprooting anthropocentric conceptions of 'nature' entails that we not only change our public moods, aesthetic-affective styles, and cultural attitudes, but also our institutions of science, politics, and so forth.

A second shortcoming of rights of nature in both Bolivia and Ecuador is their reliance on extractive industries which comprises 13 and 15 percent of their total GDP respectively (Herold 2017). Although Evo Morales promised to challenge the neo-liberal development paradigm and advance the rights of nature, the legal and political will to enforce the law has been minimal. The division between humans and nonhumans, or society and 'nature,' is still deeply embedded in Bolivia's economy, politics, and institutions of science, as detailed above. In order for posthumanist ecology to translate into practice, there must be both bottom-up pressure from new cultural attitudes, and top-down support from institutions that can reinforce these new conceptions of 'nature' and vital materiality of nonhuman entities. While the New Zealand Whanganui River Deed is not without flaws as well, it seems to do a better job of balancing between bottom-up and top-down strategies than its Ecuadorian and Bolivian counterparts.

\section{Rights of Nature in New Zealand}

The rights of nature in New Zealand have developed somewhat differently than in the cases of Ecuador and Bolivia. Instead of granting broad legal rights to nature, New Zealand has so far recognized only the Whanganui River as a rights bearing entity. There has been a long history of tension between the Maori people and New Zealand Crown over the river, dating back to the first Treaty of Waitangi in 1840. Up until the 1970s, agreements made between the Crown and Maori followed Eurocentric norms regarding private property and resource rights that were to be administered by the government (Magallanes 2015; Hsiao 2012). The Maori mobilized in the early 1970s, calling for the inclusion of their cosmology in legal and political discourse, 
culminating in the creation Waitangi Tribunal in 1975 (Magallanes 2015). The Tribunal marked the beginning of the Crown's recognition of Maori beliefs, and "the loss of Maori authority over land and resources" began to be discussed "in terms of the loss of relationships more than the loss of resource value" (Magallanes 2015, 295). Further, the Resource Management Act of 1991 specifically called for including kaitiakitanga and other Maori cultural traditions in decisionmaking regarding the stewardship of 'nature' (Magallanes 2015).

The increasing inclusion of Maori cosmology in legal frameworks has engendered a move toward rights of nature legislation in recent negotiations involving the Whanganui River. Deliberations in 2011 marked the first year of recognition of the Whanganui River as a rights bearing entity, creating a framework for future negotiations between the Whanganui Iwi and the Crown” (Hsiao 2012). In 2014, the Whanganui River Deed of Settlement—also known as Ruruku Whakatupua - entered into law. The Whanganui River Deed consists of two parts. Part one (Te Mana o Te Awa Tupua) of the deed lays out the legal framework for recognizing the river as a living entity while part two (Te Mana o Te Iwi o Whanganui) focuses on cultural and financial redress for the Maori people, including a formal apology from the Crown. The redress and apology were meant to strengthen the relationship between the Crown and the Maori and to symbolize the inclusion of the Maori people in future decision-making (NZ Government 2014). The Te Mana o Te Awa Tupua emphasizes Maori cosmology, linking their views to the rights of nature and guardianship of the Whanganui River. A textual analysis of the Whangui River Deed also reveals how Bennett's 'vital materialism' and Latour's 'parliament of things' might work in practice. 


\section{Whanganui River Deed of Settlement}

The Whanganui River Deed is written in both English and the native Maori language and focuses on the intrinsic value of the river as understood by the Maori people. Section 2 of the document makes clear that the river, called Te Awa Tupua by the Maori, is a legal person and living entity. The Maori saying, "I am the river and the river is me" is frequently invoked throughout the document as it symbolizes the Maori peoples' "inalienable interconnection with, and responsibility to Te Awa Tupua and its health and wellbeing" (Section 2, Article 7.3). Recalling from chapter three, this "inalienable interconnection" is rooted in ancestral ties to nonhuman entities known as whakapapa, and "responsibility to Te Awa Tupua" stems from the Maori practice of kaitiakitanga. It is through the recognition of Maori ties to the river as an ancestor that the river has come to possess legal status. In fact, the Deed is first and foremost, a means to advance the Maori worldview (Diprose and Bond 2016; Magallanes 2015).

The legal status of the Whanganui River came as a result of the inclusion of Maori beliefs regarding ancestral ties to nonhuman entities and the enduring bond between Maori communities and 'nature.' In this case, attitudes about 'nature' and the intrinsic vitality of nonhumans can not only translate into legal frameworks, but they can also shift the way in which we bring nonhuman entities into the political realm. This appears to be what Bennett is suggesting when she says that ecological issues are "as much a matter of culture-and-psyche-formation as [they are] of watershed management and air quality protection" (114). Indeed, Catherine Magallanes (2015) points out that "despite not stemming from the environmentalist rights of nature approach" the Whanganui River Deed was still "designed to better protect the natural environment and to better recognise an alternative relationship between humans and nature" (295). The manner in which rights of nature have played out in New Zealand seems to better 
reflect Bennett's description of how vital materialism can influence politics, rather than fitting into traditional rights discourse and western-centered legal frameworks. However, it is worth noting that the Whanganui River was only compulsorily recognized after Maori individual rights were recognized. Of course, there is no distinction between these two domains for the Maori as there is no true sense of an individual separate from 'nature.'

Although the Deed only confers legal status onto the Whanganui River, it shares with the cases of Ecuador and Bolivia its acknowledgement of nonhumans as entities within a totality, much like assemblages and ecosystems operate. For the Maori people, the Te Awa Tupua "is a singular entity comprised of many elements and communities, working collaboratively" with the common purpose to ensure the longevity of the entire system (Section 2, Article 7.4). To recognize the Maori worldview in law is to simultaneously recognize the inherent rights and significance of every other entity bound up with the Maori way of life. This is especially true in the case of Maori indigenous peoples whose cultural rights are not only dependent on the recognition of nonhuman entities as vital materialities, but also on the Maori people's ability to care for them. Unlike the legal frameworks in Ecuador and Bolivia, the Whanganui River Deed specifically appoints several representatives to speak on behalf of the river in terms of its health, wellbeing, and importance to Maori communities.

\section{Implementation and Enforcement}

Section 3 of the Whanganui River Deed deals specifically with the appointment of the Te Pou Tupua, a singular "role exercised jointly by two persons" who are to be the "human face and act in the name of" the Whanganui River (Articles 3.7 and 3.1, respectively). The Te Pou Tupua representatives have a lot in common with Latour's spokespersons, and are better defined than the Defensoría de la Madre Tierra of Brazil. Rather than being scientists themselves, who 
collaborate with politicians on matters of concern, the Te Pou Tupua act as a liaison between different sectors within society. They not only engage with Maori community members on the status of the river in terms of cultural indicators, such as the $\mathrm{CHI}$, but also all relevant agencies who regularly report on the river's status (Section 3, Articles 4.1-4.5). Moreover, they have a public role to report matters of concern involving the river to the proper authorities, while also having the power to "develop and review guidelines and policies" that pertain to ensuring the river's wellbeing (Section 3, Articles 4.3-4.4).

There are two important rules that involve the appointment of the Te Pou Tupua representatives. First, they are to be experts "of high standing, recognising both the importance of the role and the need to interact with Ministers and other agencies, Iwi and Hapu [Maori tribes], organisations, and communities at a leadership level” (Section 3, Article 3.8). Second, one of the representatives is to be from the New Zealand Crown, jointly appointed by the Minster of Treaty Negotiations and the Minister of Justice, and the other a Maori person, appointed democratically from the Iwi tribe (Section 3, Articles 18-23). The Deed also establishes a budget for the office of the Te Pou Tupua at $\$ 200,000$ a year until at least 2035 (NZ Department of Treasury 2015). Remarkably, representation for the Whanganui River does not stop at the Te Pou Tupua as there is also an advisory group consisting of 6 members from municipal authorities and a strategy group consisting of 17 members (Section 3, Articles 27-28). The strategy group is to be assembled from several stakeholder groups including, but not limited to, the Director-General of Conservation, the NZ Fish and Game Council, the energy, tourism, and primary industry sectors, and several different environmental organizations (Section 4, Articles 29-34). 
The appointment of various stakeholders who are to speak on behalf of the Whanganui River and their relative interests conforms with Bruno Latour's proposal that we should not "homogenize those which participate in the power" to prioritize and take into account what is important for collective life $(2004,113)$. This consultation process is a key requirement in Latour's 'parliament of things.' If an issue were to arise regarding the health of the Whanganui River, every stakeholder would have a different perspective on the problem and different level of expertise in the matter. As Latour puts it, "laboratories do research, farmers investigate, consumers worry, veterinarians point out symptoms, epidemiologists analyze their statistics, journalists probe, cows mill about, [and] sheep get the shakes" $(2010,112)$. While each spokesperson should be aware of their own limits and interests in speaking on behalf of the Whanganui River, it is also important that the consultation process be democratic and deliberative in nature. What is most interesting in the case of New Zealand spokespersons is that, as their cultural practices indicate, Maori interests in the river will not be vested in its monetary and instrumental value, but in its intrinsic value as a lively materiality. The opening up of political discourse to include Maori cosmologies provides a potential avenue for a broader cultural diffusion of conceptions about nonhuman entities and 'nature.'

Although this consultation process may provide a useful vehicle for the Maori to spread their conception of 'nature' to other groups within New Zealand society, the Whanganui River Deed is not without criticism. As Hutchison (2014) points out, "parts of the river that were privately owned will remain privately owned, and will continue to be seen as property" (9). This means the rights of the river are upheld only insofar as they do not conflict with the wellestablished, western practice of the human right to property. Although New Zealand has included Maori beliefs into the framework of the Deed, it still does not legally challenge hierarchies of 
power, either between the Crown and Maori, or humans and 'nature.' However, including indigenous views in legal frameworks can challenge hierarchies of power through the normalization of alternative worldviews. While some scholars (Scheingold 1974; Kalman 1996) have argued that laws are entrenched in already established hierarchies of power and cannot produce lasting social and cultural change, others have argued that laws can be powerful tools for empowering activists and changing attitudes and behavior (Cooter 1998; Sunstein 1996; Silverstein 1996; McCann 1998). What sets the above rights of nature laws apart from this scholarship is that there are already indigenous peoples providing evidence of how these alternative belief systems can work in community-level practice. In so doing, they are also giving us a glimpse of the potential benefits of post-humanist ecologies as they move from social practices to legal and political discourse. 


\section{CHAPTER V: CONCLUSION}

Rights of nature laws can tell us quite a bit about the potential political implications of post-humanist ecologies. In particular, post-humanist ecologies can shape new cultural attitudes and inform new political and legal discourses that are mutually reinforcing. Indigenous Amazonian and Maori practices and beliefs tell us that we can build ecologically-minded communities by recognizing the vitality of nonhuman entities and our interconnectedness with 'nature.' When we look closely through their lenses, we can begin to uncover the various actants with whom we share agency. As Bennett suggests, these conceptions of nonhuman human entities can create a new self-interest. That is, if we step outside ourselves, we can see that it is not the monetary value of 'things' and liberal philosophies of individualism that define who 'we' are, but the actions of many interdependent human and nonhuman bodies and forces. For now, rights of nature laws tell us that when post-humanist perspectives of ecology move into the political realm, there are several concurrent procedures that must follow.

While it may be possible to include indigenous cosmologies and post-humanist concepts in the text of legal documents, rights of nature implementation and enforcement in Ecuador, Bolivia, and New Zealand indicate that it is not nearly as easy to carry them out in practice. This is especially the case when deeply embedded hierarchies of power and neo-liberal economics already govern political systems throughout the world. Fortunately, Latour provides us with some indications for what a politics including nonhuman nature should look like. While rights of nature laws in Ecuador and Bolivia do not provide adequate representation for nonhumans, New Zealand's Whanganui River has a healthy assortment of parties who can collaborate on its wellbeing. However, even New Zealand's law is undermined by private property rights which places the river in a strange predicament, wherein it is both an object to be owned and a vibrant 
materiality to be valued in its own right. This predicament reveals that it is not enough to put in place spokespersons, no matter how many there are, as they still risk being restricted by prevailing sentiments of (and rules governing) a neo-liberal, capitalist society. It is difficult to tell which should come first in this respect, i.e. should we focus our attention on creating a bottom-up cultural disposition oriented toward the intrinsic value of nonhuman entities, or the top-down legal mechanisms that can ensure they are recognized as lively materialities by the state? Of course, there is no easy answer to this question. As I discussed in the last chapter, rights of nature seem to require more than just a shift in legal frameworks. Economic, scientific, and even educational institutions will need to be reworked to reflect post-humanist perspectives. This leads me to believe that bottom-up reconfigurations of cultural attitudes are indispensable to a successful post-humanist political project.

It is worth noting that rights of nature laws have been born out of a political context that is currently evolving. On the one hand, indigenous peoples in Ecuador, Bolivia, and New Zealand have been gaining more rights and political recognition. On the other hand, they must assimilate their beliefs and practices into western-centered legal frameworks even when those frameworks run contrary to their cosmologies. This collision of ideologies provides an interesting glimpse of the challenges post-humanist ecologies may face as they move into the political and legal realm. Although I have outlined several connections between post-humanist ecologies and indigenous imaginaries, not all Amazonian and Maori beliefs and practices are entirely representative of these post-humanist concepts. Studying other indigenous belief systems may shed new light into how post-humanist ecologies might work in practice. Or, there may be other, nonindigenous groups that already exist or are currently mobilizing around post-humanist perspectives. Certainly, ongoing research should keep track of these developments. Meanwhile, 
other studies may want to explore how local level rights of nature laws have been gaining momentum and what challenges they face as they too might provide insight into possible political implications of post-humanist ecologies.

For now, we know that post-humanist ecologies can inform ecologically-minded practices as indigenous practices and beliefs have indicated. Moving further into the Anthropocene will hopefully inspire a more robust move toward ecologically-minded politics. Whether or not post-humanist perspectives of ecology will be the philosophy states adopt in future political and legal frameworks remains to be seen. For now, we do know is that it is possible to incorporate post-humanist perspectives of ecology into western-legal frameworks as the cases of Ecuador, Bolivia, and New Zealand have indicated. If we continue to create new public moods that reflect these philosophies, the political momentum and will to challenge old hierarchies of power will only grow stronger and become more effective in addressing the ecological problems of our time. 


\section{REFERENCES}

Akchurin, Maria. 2015. "Constructing the Rights of Nature: Constitutional Reform, Mobilization, and Environmental Protection in Ecuador." Law \& Social Inquiry 40(4): 937-968.

Babcock, Hope M. 2016. "A Brook with Legal Rights: The Rights of Nature in Court." Ecology Law Quarterly 43(1): 1-51.

Balée, William. 2003. "Native Views of the Environment in Amazonia" in Nature Across Cultures: Views of Nature and the Environment in Non-Western Cultures, ed. Helaine Selin. Kluwer Academic Publishers: Boston. 277-288.

Bennett, Jane. 2010. Vibrant Matter: A Political Ecology of Things. Duke University Press: London.

Beyer, Stephen V. 2009. Singing to the Plants: A Guide to Mestizo Shamanism in the Upper Amazon. University of New Mexico Press: Albuquerque.

Blaser, Mario. 2014. "Ontology and Indigeneity: On the Political Ontology of Heterogeneous Assemblages." Cultural Geographies 21(1): 49-58.

Brei, Andrew. 2013. "Rights \& Nature." Journal of Agricultural \& Environmental Ethics 26(2): $393-408$.

Browman, David L. 2003. "Central Andean Views of Nature and the Environment” in Nature Across Cultures: Views of Nature and the Environment in Non-Western Cultures, ed. Helaine Selin. Kluwer Academic Publishers: Boston. 289-310.

Burbach, Roger. 2007. "Ecuador's Popular Revolt: Forging a New Nation." NACLA Report on the Americas 40(5): 4-9. 
Burdon, Peter. 2010. "The Rights of Nature: Reconsidered." Australian Humanities Review 49: 69-89.

Bussmann, Rainer W. and Douglas Sharon. 2006. “Traditional Medicinal Plant Use in Loja Province, Southern Ecuador." Journal of Ethnobiology and Ethnomedicine 2(10): $44-55$.

Chávez, Franz. 2014. "Bolivia’s Mother Earth Law Hard to Implement.” Inter Press Service: News and Views of the Global South. http://www.ipsnews.net/2014/05/bolivias-motherearth-law-hard-implement/.

Chiriboga, Manual. 1987. "Movimiento Campesino e Indígena y Participación Política en Ecuador: La Construcción de Identidades en una Sociedad Heterogénea.” Ecuador Debate 13: $87-121$.

Colón-Ríos, Joel I. 2015. "On the Theory and Practice of the Rights of Nature” in The Search for Environmental Justice, Paul Martin, et al., eds. Edward Elgar Publishing: Cheltenham, UK. 120-135.

Constitution of the Republic of Ecuador. Ratified by the Constituent Electorate 28 September, 2008. English: http://pdba.georgetown.edu/Constitutions/Ecuador/english08.html.

Cooter, Robert. 1998. "Expressive Law and Economics." Journal of Legal Studies 27: 585-608.

Daly, Erin. 2012. "The Ecuadorian Exemplar: The First Ever Vindications of Constitutional Rights of Nature.” Review of European Community \& International Environmental Law 21(1): 63-66.

De Castro, Eduardo Viveiros. 2002. A Inconstância da Alma Selvagem. Cosac e Naify: Sao Paolo, Brazil. 
De Castro, Eduardo Viveiros. 1998. Cosmological Perspectivism in Amazonia and Elsewhere. Cambridge University Press: Boston.

Descola, Phillipe. 1996. "Constructing Natures Symbolic Ecology and Social Practice" in Nature and Society: Anthropological Perspective, Pálsson Gísli and Philippe Descola, eds. Routledge: New York. 82-102.

Diprose, Gradon, A. C. Thomas, and S. Bond. 2016. "'It's Who We Are': Eco-Nationalism and Place in Contesting Deep-Sea Oil in Aotearoa New Zealand." Kotuitui: New Zealand Journal of Social Sciences 11(2): 159-173.

Espinosa, Cristina. 2014. "The Advocacy of the Previously Inconceivable: A Discourse Analysis of the Universal Declaration of the Rights of Mother Earth at Rio+20." Journal of Environment \& Development 23(4): 391-416.

Gedicks, Al. 1993. The New Resource Wars: Native and Environmental Struggles Against Multinational Corporations. South End Press: Cambridge, MA.

Global Alliance for the Rights of Nature. 2016. "Ecuador Adopts Rights of Nature in Constitution." http://therightsofnature.org/ecuador-rights/.

Good, Meg. 2013. "The River as a Legal Person: Evaluating Nature Rights-Based Approaches to Environmental Protection in Australia." National Environmental Law Review 1: 34-42.

Harmsworth, Garth R., et al. 2011. "Linkages between Cultural and Scientific Indicators of River and Stream Health." New Zealand Journal of Marine and Freshwater Research 45(3): 423-436.

Harvey, Graham. 2006. Animism: Respecting the Living World. Columbia University Press: New York. 
Henning, Brian G. 2016. "Unearthing the Process Roots of Environment Ethics: Whitehead, Leopold, and the Land Ethic.” Balkan Journal of Philosophy 8(1): 3-12.

Hicks, Kevin and Fabricant N. 2013. "The Bolivian Climate Justice Movement" Latin American Perspectives 43(4): 87.

Hsiao, Elaine C. 2012. "New Zealand: Whanganui River Agreement - Indigenous Rights and Rights of Nature." Environmental Policy and Law: 42(6). 371-375.

Hutchison, Abigail. 2014. "The Whanganui River as a Legal Person." Alternative Law Journal 39(3): 179-182.

Kalman, Laura. 1996. The Strange Career of Legal Liberalism. Yale University Press: New Haven, CT.

Kauffmann, Craig and Pam Martin. 2016. "Testing Ecuador's Rights of Nature: Why Some Lawsuits Succeed and Others Fail." Presented at the International Studies Association Annual Convention, Atlanta, GA, March 18, 2016.

Kawharu, Merata. 2000. "Kaitiakitanga: A Maori Anthropological Perspective of the Maori Socio-Environmental Ethic of Resource Management." The Journal of the Polynesian Society 109(4): 349-370.

LaDuke, Winona. 1999. All Our Relations: Native Struggles for Land and Life. South End Press: Cambridge, MA.

Lalander, Rickard. 2014. "Rights of Nature and the Indigenous Peoples in Bolivia and Ecuador: A Straitjacket for Progressive Development Politics?" Journal of Development Studies 2: $148-173$. 
Latour, Bruno. 2014. "What is the Style of Matters of Concern" in The Lure of Whitehead, Nicholas Gaskill and A.J. Nocek, eds. University of Minnesota Press: Minneapolis. 92126.

Latour, Bruno. 2004. Politics of Nature: How to Bring the Sciences into Democracy. Translated by Catherine Porter. Harvard University Press: Cambridge, MA.

Magallanes, Catherine J. Iorns. 2015."Maori Cultural Rights in Aotearoa New Zealand: Protecting The Cosmology That Protects the Environment." Widener Law Review: 21(2). 273-327.

McCann, Michael W. 1998. "How Does Law Matter for Social Movements," in How Does Law Matter? B. Garth \& A. Sarat, eds. Northwestern University Press: Evanston, IL.

Nash, Roderick Frazier. 1989. The Rights of Nature: A History of Environmental Ethics. The University of Wisconsin Press: Madison.

New Zealand Government. 2016. "Whanganui Iwi (Whanganui River) Deed of Settlement Summary.” https://www.govt.nz/treaty-settlement-documents/whanganui-iwi/whanganuiiwi-whanganui-river-deed-of-settlement-summary-5-aug-2014/.

New Zealand Depart of the Treasury. 2015. "Estimates of Appropriations- Te Pou Tupua" (M29). http://www.treasury.govt.nz/budget/2015/estimates/v3/076.htm.

Posey, Darrell A. 1983. "Folk Apiculture of the Kayapo Indians of Brazil." Biotropica 15(2): $154-158$.

Hunt, Sarah. 2014. Ontologies of Indigeneity: The Politics of Embodying a Concept. Cultural Geographies 21(1): 27-32.

Scheingold, Stuart A. 1974. The Politics of Rights: Lawyers, Public Policy, and Political Change. Yale University Press: New Haven, CT. 
Selin, Helaine. 2003. Nature Across Cultures: Views of Nature and the Environment in NonWestern Cultures. Kluwer Academic Publishers: Boston.

Sheehan, Linda. 2015. "Implementing Rights of Nature through Sustainability Bills of Rights." New Zealand Journal of Public \& International Law 13(1): 89-106.

Sheehan, Linda. 2012. "Recognizing the Rights of Nature." The Future We Want. Earth Law Center: Fremont, CA.

Siewers, Alfred Kentigern. 2014. Re-Imagining Nature: Environmental Humanities and Ecosemiotics. Bucknell University Press: Lanham, MD.

Silverstein, Helena. 1996. Unleashing Rights: Law, Meaning, and the Animal Rights Movement. Univ. of Michigan Press: Ann Arbor.

Stone, Christopher D. 1972. “Should Trees Have Standing? Toward Legal Rights for Natural Objects." Southern California Law Review: 45. 450-501.

Strathern, Marilyn. 1999. Property, Substance and Effect: Anthropological Essays on Persons and Things. Athlone Press: London.

Sundberg, Juanita. 2014. "Decolonizing Posthumanist Geographies." Cultural Geographies 21(1): 33-47.

Sunstein, Cass R. 1996. “Social Norms and Social Roles.” Columbia Law Review 96: 903-68.

Te Ahukaramū, Charles Royal. 2007. "Kaitiakitanga - Guardianship and Conservation Understanding Kaitiakitanga.” Te Ara - the Encyclopedia of New Zealand. http://www.TeAra.govt.nz/en/kaitiakitanga-guardianship-and-conservation/page-1.

The Law of the Rights of Mother Earth. 2010. Bolivian Law 071. Adopted by the Plurinational Legislative Assembly December, 2010. 
Torres-Spelliscy, Ciara. 2014. "The History of Corporate Pershonhood.” Brennan Center for Justice at New York University School of Law. https://www.brennancenter.org/hobbylobby-argument.

Universal Declaration on the Rights of Mother Earth. 2010. Outcome Document: World People's Conference on Climate Change and the Rights of Mother Earth. Cochabamba, Bolivia April 22, 2010.

Vilaca, Aparecida. 2005. "Chronically Unstable Bodies: Reflections on Amazonian Corporalities." Journal- Royal Anthropological Institute 11(3): 445-464.

Whanganui River Deed of Settlement. 2014. New Zealand Crown Land Deed and Legal History of the Whanganui River. https://www.govt.nz/treaty-settlementdocuments/ whanganui-iwi/whanganui-iwi-whanganui-river-deed-of-settlement-summary-5.

Wheeler c. Director de la Procuraduria General Del Estado de Loja. Ecuadorian Law No. 11121-2011-0010. March 2011.

Whitehead, Alfred North. 1927-28. Process and Reality: An Essay in Cosmology from the Gifford Lectures Delivered at University of Edinburgh. David Ray Griffin and Donald W. Sherburne, eds. (1978). The Free Press, Macmillan Publishing Company: New York. World Animal Protection. 2014. Animal Projection Index. http://api.worldanimal protection.org/indicators. 


\section{APPENDIX A: ECUADORIAN CONSTITUTION (EXCERPT)}

Chapter 1- Entitlement.

Persons and people have the fundamental rights guaranteed in this Constitution and in the international human rights instruments. Nature is subject to those rights given by this Constitution and Law.

Chapter 7- Rights of Nature

Article 71. Nature, or Pachamama, where life is reproduced and occurs, has the right to integral respect for its existence and for the maintenance and regeneration of its life cycles, structure, functions and evolutionary processes. All persons, communities, peoples and nations can call upon public authorities to enforce the rights of nature. To enforce and interpret these rights, the principles set forth in the Constitution shall be observed, as appropriate. The State shall give incentives to natural persons and legal entities and to communities to protect nature and to promote respect for all the elements comprising an ecosystem.

Article 72. Nature has the right to be restored. This restoration shall be apart from the obligation of the State and natural persons or legal entities to compensate individuals and communities that depend on affected natural systems. In those cases of severe or permanent environmental impact, including those caused by the exploitation of nonrenewable natural resources, the State shall establish the most effective mechanisms to achieve the restoration and shall adopt adequate measures to eliminate or mitigate harmful environmental consequences.

Article 73. The State shall apply preventive and restrictive measures on activities that might lead to the extinction of species, the destruction of ecosystems and the permanent alteration of natural cycles. The introduction of organisms and organic and inorganic material that might definitively alter the nation's genetic assets is forbidden.

Article 74. Persons, communities, peoples, and nations shall have the right to benefit from the environment and the natural wealth enabling them to enjoy the good way of living. Environmental services shall not be subject to appropriation; their production, delivery, use and development shall be regulated by the State. 


\section{APPENDIX B: BOLIVIAN LAW ON THE RIGHTS OF MOTHER EARTH}

Chapter 1: Objects and Principles

Article 1. (Scope). This Act is intended to recognize the rights of Mother Earth, and the obligations and duties of the Multinational State and society to ensure respect for these rights.

Article 2. (Principles). The binding principles that govern this law are:

1. Harmony. Human activities, within the framework of plurality and diversity, should achieve a dynamic balance with the cycles and processes inherent in Mother Earth.

2. Collective good. The interests of society, within the framework of the rights of Mother Earth, prevail in all human activities and any acquired right.

3. Guarantee of the regeneration of Mother Earth. The state, at its various levels, and society, in harmony with the common interest, must ensure the necessary conditions in order that the diverse living systems of Mother Earth may absorb damage, adapt to shocks, and regenerate without significantly altering their structural and functional characteristics, recognizing that living systems are limited in their ability to regenerate, and that humans are limited in their ability to undo their actions.

4. Respect and defend the rights of Mother Earth. The State and any individual or collective person must respect, protect and guarantee the rights of Mother Earth for the well-being of current and future generations.

5. No commercialism. Neither living systems nor processes that sustain them may be commercialized, nor serve anyone's private property.

6. Multiculturalism. The exercise of the rights of Mother Earth requires the recognition, recovery, respect, protection, and dialogue of the diversity of feelings, values, knowledge, skills, practices, skills, transcendence, transformation, science, technology and standards, of all the cultures of the world who seek to live in harmony with nature.

Chapter II: Mother Earth, Definition and Character

Article 3. (Mother Earth). Mother Earth is a dynamic living system comprising an indivisible community of all living systems and living organisms, interrelated, interdependent and complementary, which share a common destiny. Mother Earth is considered sacred, from the worldviews of nations and peasant indigenous peoples.

Article 4. (Living Systems). Living systems are complex and dynamic communities of plants, animals, microorganisms and other beings and their environment, where human communities and the rest of nature interact as a functional unit under the influence of climatic, physiographic, and geological factors, as well as production practices, Bolivian cultural diversity, and the worldviews of nations, original indigenous peoples, and intercultural and Afro-Bolivian communities.

Article 5. (Legal Status of Mother Earth). For the purpose of protecting and enforcing its rights, Mother Earth takes on the character of collective public interest. Mother Earth and all its 
components, including human communities, are entitled to all the inherent rights recognized in this Law. The exercise of the rights of Mother Earth will take into account the specificities and particularities of its various components. The rights under this Act shall not limit the existence of other rights of Mother Earth.

Article 6. (Exercise of the Rights of Mother Earth). All Bolivians, to join the community of beings comprising Mother Earth, exercise rights under this Act, in a way that is consistent with their individual and collective rights. The exercise of individual rights is limited by the exercise of collective rights in the living systems of Mother Earth. Any conflict of rights must be resolved in ways that do not irreversibly affect the functionality of living systems.

\section{Chapter III: Rights of Mother Earth}

Article 7. (Rights of Mother Earth). Mother Earth has the following rights:

1. To life: The right to maintain the integrity of living systems and natural processes that sustain them, and capacities and conditions for regeneration.

2. To the diversity of life: It is the right to preservation of differentiation and variety of beings that make up Mother Earth, without being genetically altered or structurally modified in an artificial way, so that their existence, functioning or future potential would be threatened. 3. To water: The right to preserve the functionality of the water cycle, its existence in the quantity and quality needed to sustain living systems, and its protection from pollution for the reproduction of the life of Mother Earth and all its components.

4. To clean air: The right to preserve the quality and composition of air for sustaining living systems and its protection from pollution, for the reproduction of the life of Mother Earth and all its components.

5. To equilibrium: The right to maintenance or restoration of the interrelationship, interdependence, complementarity and functionality of the components of Mother Earth in a balanced way for the continuation of their cycles and reproduction of their vital processes.

6. To restoration: The right to timely and effective restoration of living systems affected by human activities directly or indirectly.

7. To pollution-free living: The right to the preservation of any of Mother Earth's components from contamination, as well as toxic and radioactive waste generated by human activities. Chapter IV: State Obligations and Societal Duties

Article 8. (Obligations of the Plurinational State). The Plurinational State, at all levels and geographical areas and across all authorities and institutions, has the following duties:

1. Develop public policies and systematic actions of prevention, early warning, protection, and precaution in order to prevent human activities causing the extinction of living populations, the alteration of the cycles and processes that ensure life, or the destruction of livelihoods, including cultural systems that are part of Mother Earth.

2. Develop balanced forms of production and patterns of consumption to satisfy the needs of the Bolivian people to live well, while safeguarding the regenerative capacity and integrity of the cycles, processes and vital balance of Mother Earth. 
3. Develop policies to protect Mother Earth from the multinational and international scope of the exploitation of its components, from the commodification of living systems or the processes that support them, and from the structural causes and effects of global climate change.

4. Develop policies to ensure long-term energy sovereignty, increased efficiency and the gradual incorporation of clean and renewable alternative sources into the energy matrix.

5. Demand international recognition of environmental debt through the financing and transfer of clean technologies that are effective and compatible with the rights of Mother Earth, among other mechanisms.

6. Promote peace and the elimination of all nuclear, chemical, and biological arms and weapons of mass destruction.

7. Promote the growth and recognition of rights of Mother Earth in multilateral, regional and bilateral international relations.

Article 9. (Duties of the People). The duties of natural persons and public or private legal entities:

1. Uphold and respect the rights of Mother Earth.

2. Promote harmony with Mother Earth in all areas of its relationship with other human communities and the rest of nature in living systems.

3. Participate actively, individually or collectively, in generating proposals designed to respect and defend the rights of Mother Earth.

4. Assume production practices and consumer behavior in harmony with the rights of Mother Earth.

5. Ensure the sustainable use of Mother Earth's components.

6. Report any act that violates the rights of Mother Earth, living systems, and/or their components.

7. Attend the convention of competent authorities or organized civil society to implement measures aimed at preserving and/or protecting Mother Earth.

Article 10. (Defense of Mother Earth). Establishing the Office of Mother Earth Ombudsman whose mission is to ensure the validity, promotion, distribution and compliance of the rights of Mother Earth established in this Act. A special law will establish its structure, function, and attributes.

Refer to the Executive Branch for constitutional ends.

It is given in the Assembly Hall of the Plurinational Legislative Assembly, on the seventh day of the month of December two thousand and ten.

Sen. René Oscar Martínez Callahuanca

President, Chamber of Senators 


\title{
APPENDIX C: NEW ZEALAND’S WHANGANUI RIVER DEED OF SETTLEMENT
}

\author{
(EXCERPT)
}

This document, Ruruku Whakatupua - Te Mana o Te Awa, contains the agreed terms of a new legal framework for Te Awa Tupua which upholds the mana of the Whanganui River and recognises the intrinsic ties which bind the Whanganui River to the people and the people to the Whanganui River.

\section{OVERARCHING PURPOSE OF TE PA AUROA NA TE AWA TUPUA}

1.3 The overarching purpose of Te Pa Auroa na Te Awa Tupua is to provide for: 1.3.1 the legal recognition of Te Awa Tupua; 1.3.2 the legal recognition and effect of Tupua te Kawa; 1.3.3 the development and effect of Te Heke Ngahuru ki Te Awa Tupua; and 1.3.4 the protection and promotion of the health and wellbeing of Te Awa Tupua.

2. TE AWA TUPUA: An indivisible and living whole from the mountains to the sea

The Great River flows from the mountains to the sea I am the River and the River is me. Te Awa Tupua is an indivisible and living whole comprising the Whanganui River from the mountains to the sea, incorporating its tributaries and all its physical and metaphysical elements.

TE AWA TUPUA AS A LEGAL PERSON

2.2 Te Awa Tupua is a legal person.

2.3 Te Awa Tupua has the rights, powers, duties and liabilities of a legal person.

2.4 The rights, powers and duties of Te Awa Tupua must be exercised and performed on behalf of, and in the name of Te Awa Tupua:

2.4.1 by Te Pou Tupua; and

2.4.2 in accordance with this document.

2.5 Te Pou Tupua is responsible for the liabilities of Te Awa Tupua.

\section{TUPUA TE KAWA}

2.6 Tupua te Kawa is a set of intrinsic values which represents the essence of Te Awa Tupua.

2.7 Tupua te Kawa comprises:

1. Ko Te Kawa Tuatahi

Ko te Awa te matapuna o te ora (The River is the source of spiritual and physical sustenance)

Te Awa Tupua is a spiritual and physical entity that supports and sustains both the life and natural resources within the Whanganui River and the health and wellbeing of the 
iwi, hapu and other communities of the River.

2. Ko Te Kawa Tuarua

E rere kau mai te Awa nui mai i te Kahui Maunga ki Tangaroa (The great River flows from the mountains to the sea)

Te Awa Tupua is an indivisible and living whole from the mountains to the sea, incorporating the Whanganui River and all of its physical and metaphysical elements.

3. Ko Te Kawa Tuatoru

Ko au te Awa, ko te Awa ko au (I am the River and the River is me)

The iwi and hapu of the Whanganui River have an inalienable interconnection with, and responsibility to, Te Awa Tupua and its health and wellbeing.

4. Ko Te Kawa Tuawha

Nga manga iti, nga manga nui e honohono kau ana, ka tupu hei Awa Tupua

(The small and large streams that flow into one another and form one River)

Te Awa Tupua is a singular entity comprised of many elements and communities, working collaboratively to the common purpose of the health and wellbeing of Te Awa Tupua.

\section{CROWN COMMITMENT}

2.8 The Crown confirms its commitment to Te Awa Tupua and Tupua te Kawa.

\section{THE PURPOSE OF TE POU TUPUA}

3.1 The purpose of Te Pou Tupua is to be the human face and act in the name of Te Awa Tupua.

3.2 In exercising its functions Te Pou Tupua must act in the interests of Te Awa Tupua and consistently with Tupua te Kawa.

\section{FUNCTIONS OF TE POU TUPUA}

3.3 The functions of Te Pou Tupua are to:

3.3.1 act and speak on behalf of Te Awa Tupua;

3.3.2 uphold:

(a) the Te Awa Tupua status; and

(b) Tupua te Kawa;

3.3.3 Promote and protect the health and wellbeing of Te Awa Tupua; human face of Te Awa

Tupua

3.4 Without limiting clause 3.3, in exercising its functions Te Pou Tupua:

3.4.1 must, in recognising the inalienable interconnection between the iwi and hapu of the Whanganui River and Te Awa Tupua, develop appropriate mechanisms for engaging with and reporting to those iwi and hapu on matters relating to Te Awa Tupua;

3.4.2 may, from time to time, report publicly on matters relating to Te Awa Tupua; 3.4.3 may engage with any relevant agency, decision-maker or other body to assist that agency, decision-maker or body in its understanding, application and 
implementation of the Te Awa Tupua status and Tupua te Kawa including, if agreed, the development or review of relevant guidelines or policies; and

3.4.4 may participate in relevant statutory processes.

\section{CAPACITY OF TE POU TUPUA}

3.5 Te Pou Tupua has full capacity to exercise its functions.

\section{APPOINTMENT OF TE POU TUPUA}

3.6 Te Pou Tupua is, through the appointment process, symbolic of the Treaty partnership between the Crown and iwi.

3.7 Te Pou Tupua comprises a singular role exercised jointly by two persons.

3.8 The two persons to be appointed to the position of Te Pou Tupua are intended to be persons of high standing, recognising both the importance of the role and the need to interact with Ministers and other agencies, iwi and hapu, organisations and communities at a leadership level.

3.9 The two persons to be appointed to the position of Te Pou Tupua will be appointed by iwi with interests in the Whanganui River and the Crown ("appointers") as follows:

3.9.1 one person will be nominated by iwi with interests in the Whanganui River;

3.9.2 one person will be nominated by the Crown; and

3.9.3 iwi with interests in the Whanganui River and the Crown will jointly and by agreement appoint two persons to the position of Te Pou Tupua:

(a) based on the nominations referred to in clauses 3.9.1 and 3.9.2; and

(b) having regard to the joint ability of the nominees to fulfil the purpose and exercise the functions of Te Pou Tupua.

3.10 In making a nomination, the relevant nominator must be satisfied that the proposed nominee has the requisite mana, skills, knowledge and experience to achieve the purpose and exercise the functions of Te Pou Tupua.

3.11 Prior to making a nomination, each nominator must give notice to the other nominator. 3.12 Te Pou Tupua is appointed for a term of three years.

Signed, 5 August 2014

Minister for Treaty of Waitangi Negotiations and the Whanganui Iwi 